\title{
28 Research Suare \\ Situational Analysis of the impact of COVID-19 pandemic on digital health research initiatives in South Asia
}

Akash Gajanan Prabhune ( $\nabla$ akashprabhune@pacindia.org )

Public Affairs Centre, Bengaluru https://orcid.org/0000-0002-3046-9067

\section{Aishwarya Mallawaram}

Public Affairs Centre, Bengaluru

\section{Sachin Bhat}

Public Affairs Centre, Bengaluru

Ayesha Mehar Shagufta

Public Affairs Centre, Bengaluru

\section{Research Article}

Keywords: Digital Health, Sustainability Assessment, COVID-19

Posted Date: June 7th, 2021

DOl: https://doi.org/10.21203/rs.3.rs-593863/v1

License: () (i) This work is licensed under a Creative Commons Attribution 4.0 International License. Read Full License 


\section{Abstract}

The objective of this paper was to evaluate and compare the quantity, and sustainability of digital health initiatives in the South Asia region pre-pandemic and during the COVID-19 pandemic.

The study used a two-step methodology of a) Descriptive analysis of digital health research articles published from 2016-21 from South Asia in terms of stratification of research articles based on diseases and conditions they were developed, geography, tasks wherein the initiative was applied. b) A simple and replicable tool was developed by authors to assess the sustainability of digital health initiatives using Experimental or Observational study designs.

The results from descriptive analysis highlight; a) 40\% increase in the number of studies report in 2020 when compared to 2019 , b) The three most common diseases and conditions wherein substantive digital health research has been focused are Health Systems Strengthening, Ophthalmic Disorders, and COVID-19, c) Remote Consultation, Health Information delivery and Clinical Decision support systems are the top three commonly developed tools.

We developed and estimated the inter-rater operability of the sustainability assessment tool was ascertained with a Kappa value of $0.806( \pm 0.088)$.

We conclude that the COVID-19 pandemic had a positive impact on digital health research with improvement in the number of digital health initiatives and improvement in sustainability score of studies published during COVID-19.

\section{Background}

The World Health Organization Global Digital Health Strategy 2020-25 defines digital health as the field of knowledge and practice associated with the development and use of digital technologies to improve health. (1) The FITT framework developed by Ammenwerth et.al (2) for classification of Information Technology initiatives, broadly classifies the digital health initiatives into three tasks Health Information Exchange, Data Science and Surveillance(3). The WHO Global Digital Strategy stated its vision as "improving health for everyone, everywhere by accelerating the development and adoption of appropriate, accessible, affordable, scalable and sustainable person-centric digital health solutions". The vision document has highlighted four strategic objectives; a) Institutionalization of digital health in the national health system, b) Integrated strategy to ensure the success of digital initiatives, c) Promote appropriate use of digital technologies for health, d) Address the impediments faced by least developed countries implementing digital health technologies.

The COVID-19 pandemic disrupted the global healthcare systems, the increasing COVID-19 cases diverted the available health care infrastructure, resources, manpower towards controlling the pandemic, while the delivery of normal healthcare services, related to maternal and child care, Non Communicable diseases was disrupted(4-7). The disruption in normal delivery of health care services presented an opportunity for digital health initiatives to fill in the gap, with as many as 264 research papers on digital health indexed in PubMed in the year 2020 on digital health from the South Asia region as compared to 82 research papers indexed in the year 2019. The three-fold increase in Medline indexed research papers implies an increased interest of medical practitioners, researchers, academicians in digital health from developing countries like India, Bangladesh, Vietnam, Thailand, Sri Lanka, Indonesia. 
An increase in quantity is one aspect of the global digital health vision, the Quality of research undertaken and key steps are taken in the development phase to ensure the sustainability of the initiative are the two aspects that are explored to a limited extent.

In the proposed situational analysis, covers above mentioned aspects in digital health research in South Asian countries, which is home to about a quarter of the total world population. This research paper aims systematic analysis of the change in patterns measured through a review of published literature in pre-COVID-19 and during the COVID-19 pandemic.

Objective - The objective of this paper was to evaluate and compare the quantity, and sustainability of digital health initiatives in the South Asia region pre-pandemic and during the COVID-19 pandemic

\section{Methods}

A comprehensive search strategy was developed including search terms, Digital Health, mHealth, telehealth, ehealth, health information exchange, Data Science, Surveillance with appropriate bullion operators "And/Or". The search was limited to the Medline database and restricted to South Asia, English Language and 5 years (20162020).

Search terms: (((((Digital Health) OR (mHealth)) OR (tele health)) OR (e health)) AND (((Health information exchange) OR (Data Science)) OR (Surveillance)) AND (y_5[Filter])) AND (((South East Asia) OR (India)) OR (South Asia) AND (y_5[Filter]))

The study has been divided into two sections of

A) Descriptive Analysis on Number of Research articles published on digital health

All the search results will be screened for eligibility based on

- Any research article published from January 2016 till March 2021

- The research articles must be focused on either Health information exchange, Data Science, or Surveillance tasks using digital tools

The descriptive analysis will include the number of research articles published year on year from January 2016 till March 2021, stratification of research articles based on diseases and conditions they were developed, geography, tasks wherein the initiative was applied.

1. B) Assessment of Sustainability

The eligibility criteria for assessment of quality are

- Research articles published between January 2016 till March 2021

- Research articles wherein the focus was on development, validation, scaling up of the digital initiative

- Research articles using Randomized Controlled trials, Quasi-Experimental, Case-Control, Cross-Sectional, Diagnostic and Pilot study designs

The exclusion criteria for assessment of quality are 
- Research articles including Review Articles, Policy articles, Letter to Editors, Correspondence were excluded from quality assessment

- Economic Evaluation studies, Qualitative analysis studies were excluded from quality assessment

A review of various tools available for assessment of sustainability across various sectors like Manufacturing(8,9), Corporate Management(10), Multisectoral sustainability assessment tool(11), and Program Sustainability Assessment tool(12), Clinical Sustainability Assessment tool(13) developed by Centre for public health systems sciences, Washington University in St. Louis, however, none were found suitable to assess the sustainability of digital health initiatives, thus a simple tool was developed based on the objectives and vision stated in Global Digital Health Strategy 2020-2025 and principles of Public Health Data Standards(14). Two independent raters AM, SB and AS reviewed the eligible studies for three key areas a) Multisectoral and CrossSectoral engagement, b) Standards and Interoperability, c) People-Centric Approach. The sustainability score for the study was determined as the average score given by two independent raters. Table 1, presents the detailed tool used for assessing the sustainability

Table 1 - Tool of assessment of sustainability 
Study Citation

Section A - Multisectoral and Cross-Sectoral Engagement

Q1) Does the study involve a multisectoral team?

Yes

Consider

No

a) Were all the authors from the medical field only

Can't Say

$£$

b) Are the data scientists/development engineers/IT Consultants acknowledged in the paper?

(If your answer is Yes +1 , NO -1, Can't Say 0)

Q2) Does the study involve engagement with sectors other than health?

Yes

f

Consider

No

$£$

a) Concerning the study objective, did the study mention any other sectors like nutrition, agriculture

Can't Say

f

b) Were the study endpoints or outcome assessment involved data from other sectors

Section B - Standards and Interoperability

Q3) Does the study mention adherence to any standards of data components, data interchange, application-level support?

Consider

(If your answer is Yes

+1 , NO -1, Can't Say 0)

a) Data Components - Reference Information Model, data elements, data types, terminology - Standards - HL-7, SNOMED, LOINC, UMLS

b) Data interchange - Structured and free form documents, images - Standards -

Yes

No

Can't Say

(If your answer is Yes

+1 , NO -1, Can't Say 0) HL-7, ASTM

c) Application-level support - Disease registries, implementation manuals Standards - HIPAA, HL-7, ASTM, ISO

Section C - People-Centric Approach

Q4) Does the study mention stakeholder analysis/ community needs assessment/ with end-users for the development of initiative?

Consider

a) Does the study cite the previous study published on gap analysis, stakeholder analysis, qualitative survey to understand the needs of the end-users?

b) Does the study involve a section or subsection wherein end-users were involved

Yes

No

Can't Say

(If your answer is Yes +1 , NO -1, Can't Say 0) in the development of a digital health initiative

Q5) Does the study mention scope of collecting feedback from the end-users?

Yes

Consider

No

$£$

a) Was there any mention of the collection of feedback from the end-users in the paper

Can't Say

b) In the case of applications has feedback being collected and suitable changes being made to improve user-friendliness 
Our search strategy yielded a total of 563 articles on Medline, with the primary screening of article title and abstract 186 articles were found to be satisfying eligibility criteria. From 2016 to 2020 the number of research articles published on digital health has been steadily increasing and the trend over the past five years is visualized in Figure1.

When the studies were stratified based on study design, Review Articles and Guidelines made up to $65 \%$ of all the studies published on digital in past five years with a maximum number of review articles published in 2020. Figure 2 visualizes the study design and year was a trend. The year on year trend presented an average of $10 \%$ increase in Review Articles, 5\% increase in Letter to Editors and Correspondence,4\% in Diagnostic studies and 2-3\% increase in Experimental Studies, Cohort Studies, Pilot and Development studies on digital health between 2016 to 2021.

The studies were stratified based on diseases and conditions for which digital initiative was primarily targeted, across the 5 years' timeline. Health Systems Strengthening which included initiatives such as capacity building amongst healthcare staff, geo-spatial analysis for improving access to healthcare services, using data science to improve the availability of essential medicines, was the area wherein the highest digital health initiatives were focused. Ophthalmic disorders and COVID-19 was the second and third conditions to be frequently researched. The year on year trend analysis of conditions wherein digital health initiatives were primarily targeted, Ophthalmic Disorders and Health Systems Strengthening recorded $<20 \%$ increase, Cancer Screening, Cardiovascular Disorders, Mental Health recorder 4-6\% increase on an average from 2016-21.

Negative year on year trend was seen for Dental Sciences, Dermatology, Drug safety, Elderly Care, HIV prevention and control, Injuries and Accidents, Kidney and Urinary tract disorders, Leprosy Management, Neurological Conditions, Nutrition, Orthotic Disorders, Sexual and Reproductive Health, Stroke, Tobacco and Alcohol Cessation, Tuberculosis Prevention and Control, Vaccination, Vector-Borne Disease Prevention and Control

The study used the FITT framework to classify digital tools on tasks, the broad classification was Health Information Exchange, Data Science, and Surveillance. Further classification and definition with examples of each digital tool is presented in Table 2

Table 2 - Types of digital tools 


\begin{tabular}{|c|c|c|c|}
\hline $\begin{array}{l}\text { Task wise } \\
\text { classification }\end{array}$ & Sub Classification & Definition & Example \\
\hline $\begin{array}{l}\text { Health } \\
\text { Information } \\
\text { Exchange } \\
(\mathrm{HIE})\end{array}$ & Data Sharing & $\begin{array}{l}\text { Any tool a platform has } \\
\text { to support data sharing } \\
\text { between heterogeneous } \\
\text { computer systems of } \\
\text { different } \\
\text { organizations(15) }\end{array}$ & $\begin{array}{l}\text { Health } \\
\text { Information } \\
\text { and } \\
\text { management } \\
\text { system }\end{array}$ \\
\hline
\end{tabular}

Information A tool used for delivery of information

delivery (preventive, curative) to the end-users
SMS's sent for a reminder of upcoming health visit,

Consultation using

Skype, Zoom

$\begin{array}{lll}\begin{array}{ll}\text { Remote } \\ \text { Consultation }\end{array} & \begin{array}{l}\text { Consultation by remote telecommunications, } \\ \text { generally for diagnosis or treatment of a patient } \\ \text { at a site remote from the patient or primary }\end{array} & \begin{array}{l}\text { Consultation using } \\ \text { Skype, Zoom }\end{array}\end{array}$
physician(16)

Intelligent Intelligent Diagnosis systems are capable of

Diagnosis identifying the nature of a problem by examining the observed symptoms and possibly an explanation or justify the same(17)

Algorithm-based diagnosis of risk of developing Diabetes

Health-related data created, gathered or inferred by or from patients and for which the patient controls data collection and data sharing(18)

\section{Predictions on chances} of raining analytics that makes predictions about future outcomes using historical data combined with statistical modelling, data mining techniques and machine learning(19)
Predictive
Analytics

\section{Tools designed to be direct aid to clinical}

Clinical

Decision

Support

System decision making, in which the characteristics of an individual patient are matched to a computerized clinical knowledge base and patient-specific assessments or recommendations are then presented to the clinician for a decision(20)

$\begin{array}{ll}\text { Big Data } & \text { Big data analytics covers the integration of } \\ \text { Mining } & \text { heterogeneous data, data quality control, } \\ & \text { analysis, modelling, interpretation and } \\ & \text { validation(21) }\end{array}$

Surveillance Risk Screening
Image-based computerassisted screening of oral lesions for cancer screening

$\begin{array}{lll}\text { Data Science } & \text { Patient-Generated Health Data } & \begin{array}{l}\text { Health-related data } \\ \text { created, gathered or } \\ \text { inferred by or from }\end{array} \\ & \text { patients and for which } \\ \text { the patient controls data } & \text { collection and data } \\ \text { sharing(18) }\end{array}$

Health and management system 
The studies on remote consultation were most commonly reported, followed by information delivery systems and clinical decision support systems as visualized in Figure 4.

Cross-tabulation of Conditions and type of digital tool used is visualized in Figure 5; Health Information Exchange has been the most common digital tool for the majority of conditions, while all the digital initiatives in Metabolic Disorders (Diabetes), Tobacco and Alcohol Cessation, HIV prevention and Control were found to of Health Information Exchange. Surveillance initiatives were commonly employed for Vector-Borne Diseases Control, Cardiovascular disorders, COVID-19 and Health Systems Strengthening. Data Science initiatives were common for Ophthalmic Disorders, Health Systems Strengthening.

The year on year trend analysis of digital tool used, presented an average annual increase in Health Information Exchange tools recorded $5 \%$ annual increase, under $\mathrm{HIE}$, Remote consultation recorded a $9 \%$ average annual increase, followed by a $7 \%$ increase by Health Information Delivery. Data Science tools recorded a $0.5 \%$ annual increase, under DS tools only Clinical Decision Support Systems recorded a $2.5 \%$ average annual increase, whereas Big data Mining, Predictive Analysis and Patient-Generated Health Data tools recorded a negative year on year trend.

The Surveillance tools usage trend presented a 0.5\% average annual increase for 2016-2021 with Real-time Data Collection and Visualization tools showing a $2 \%$ increase.

The Descriptive analysis highlights

- COVID-19 pandemic has positively impacted digital health research with a $40 \%$ increase in the number of studies report in 2020 when compared to 2019

- The three most common diseases and conditions wherein substantive digital health research has been focused on are Health Systems Strengthening, Ophthalmic Disorders, and COVID-19.

- Remote Consultation, Health Information delivery and Clinical Decision support systems are the top three commonly developed tools from $2016-2021$

The details of all the studies included, their classification based on year, diseases, digital tools are included in the supplementary material.

\section{B) Assessment of Sustainability.}

\section{Validation of Sustainability assessment tool}

We use inter-rater operability as an indicator to measure the ease of replicability of the tool. An independent rater, assessed 30 randomly selected studies using a computer-generated list for the 87 articles assessed in section B of this study. Cohen's Unweighted Kappa was used to determine the inter-rater operability. Overall Kappa value was 0.806 (SD \pm 0.088 ). The highest inter-rater operability was seen for Q1 (Does the study involve multisectoral team?) with Kappa value $1(100 \%)$, lowest inter-rater operability was seen for Q3 (Does the study mention adherence to any standards of data components, data interchange, application-level support?) with Kappa value 0.54 $(\mathrm{SD} \pm 0.036)$. 
Kappa Value for other questions was

Q2 (Does the study involve engagement with sectors other than health?) - 0.91 (SD 0.066)

Q4 (Does the study mention stakeholder analysis/ community needs assessment/ with end-users for development of initiative?) - 0.84 (SD 0.042)

Q5 (Does the study mention scope of collecting feedback from the end-users?) - 0.71 (SD 0.06)

The interpretation of results was divided into Studies published pre COVID-19 pandemic (2016-2019) and during the COVID-19 pandemic (2020-2021). Analysis was reported for study design

\section{Experimental Study Design}

All the experimental studies pre-pandemic and during pandemic had an active involvement of IT, Data management team while developing the intervention and were either part of the team writing manuscript or dully acknowledged indicating the multisectoral team involved in developing and testing of the initiatives.

10 out of 18 experimental studies involved engagement of multiple sectors, for example, Swendenmen et, al (25) included behavioural scientist, HIV care providers, Front line health workers for the implementation of the study.

All the experimental studies mentioned adherence to data standards like WHO or ICDS classification of diseases, however, adherence to data interchange standards like HL7, was not mentioned.

All the experimental studies have either conducted a gap analysis or referred to previously published authors papers on gap analysis, community needs assessment for the development of initiatives

All the experimental studies have mentioned feedback collection from end-users, delivery providers and have mentioned changes made in digital initiative upon receiving feedback.

Overall the average sustainability of experimental studies on digital health was $80 \%$, and there was no statistically significant difference in overall sustainability score between the studies published Pre-pandemic (85.6\%) and During Pandemic (76.4\%) (p-value -0.33).

Table 3 and Figure 6 presents the study wise assessment score summary and percentage of sustainability scores based on the author's judgement.

Table 3 - Assessment of Sustainability of Experimental Studies 


\begin{tabular}{|c|c|c|c|c|c|c|}
\hline & Author & $\begin{array}{l}\text { Does the } \\
\text { study } \\
\text { involve a } \\
\text { multisectoral } \\
\text { team? }\end{array}$ & $\begin{array}{l}\text { Does the } \\
\text { study } \\
\text { involve } \\
\text { engagement } \\
\text { with sectors } \\
\text { other than } \\
\text { health? }\end{array}$ & $\begin{array}{l}\text { Does the } \\
\text { study mention } \\
\text { adherence to } \\
\text { any standards } \\
\text { of data } \\
\text { components, } \\
\text { data } \\
\text { interchange, } \\
\text { application- } \\
\text { level support? }\end{array}$ & $\begin{array}{l}\text { Does the study } \\
\text { mention } \\
\text { stakeholder } \\
\text { analysis/ } \\
\text { community } \\
\text { needs } \\
\text { assessment/ } \\
\text { with end-users } \\
\text { for the } \\
\text { development of } \\
\text { the initiative? }\end{array}$ & $\begin{array}{l}\text { Does the } \\
\text { study } \\
\text { mention } \\
\text { scope of } \\
\text { collecting } \\
\text { feedback } \\
\text { from the } \\
\text { end- } \\
\text { users? }\end{array}$ \\
\hline $\begin{array}{l}\text { During } \\
\text { COVID-19 } \\
\text { pandemic }\end{array}$ & $\begin{array}{l}\text { Shekhawat } \\
\text { et.al } \\
2020(26)\end{array}$ & Yes & No & Yes & Yes & Yes \\
\hline $\begin{array}{l}\text { Swendeman } \\
\text { et.al } \\
2020(25)\end{array}$ & Yes & Yes & Yes & Yes & Yes & \\
\hline $\begin{array}{l}\text { Johri et.al } \\
2020(27)\end{array}$ & Yes & No & Yes & Yes & Yes & \\
\hline $\begin{array}{l}\text { Suryavanshi } \\
\text { et.al } \\
2020(28)\end{array}$ & Yes & Can't Say & Yes & Yes & Yes & \\
\hline $\begin{array}{l}\text { Nandita et.al } \\
2020(29)\end{array}$ & Yes & Yes & Yes & Yes & Yes & \\
\hline $\begin{array}{l}\text { Pre COVID- } \\
19 \\
\text { Pandemic }\end{array}$ & $\begin{array}{l}\text { Modi et.al } \\
\text { 2019(30) }\end{array}$ & Yes & No & Yes & Yes & Can't Say \\
\hline $\begin{array}{l}\text { Zhilian et.al } \\
2019(31)\end{array}$ & Yes & Yes & Yes & Yes & Yes & \\
\hline $\begin{array}{l}\text { Joshep et.al } \\
\text { 2019(32) }\end{array}$ & Yes & Yes & Can't Say & Yes & Yes & \\
\hline $\begin{array}{l}\text { Saran et.al } \\
2019(33)\end{array}$ & Yes & Yes & Yes & Yes & Yes & \\
\hline $\begin{array}{l}\text { Gross et.al } \\
2019(34)\end{array}$ & Yes & Can't Say & Yes & Yes & Yes & \\
\hline $\begin{array}{l}\text { Jiang et.al } \\
2019 \text { (35) }\end{array}$ & Yes & Yes & Yes & Yes & Yes & \\
\hline $\begin{array}{l}\text { Peiris et.al } \\
2019(36)\end{array}$ & Yes & Yes & Yes & Yes & Yes & \\
\hline $\begin{array}{l}\text { Roohippor } \\
\text { et.al } \\
2019(37)\end{array}$ & Yes & No & Yes & Yes & Yes & \\
\hline $\begin{array}{l}\text { Prabhakaran } \\
\text { et.al } \\
2018(38)\end{array}$ & Yes & No & Can't Say & Yes & Yes & \\
\hline $\begin{array}{l}\text { Zhang et.al } \\
2017(39)\end{array}$ & Yes & Yes & Can't Say & Yes & Yes & \\
\hline Ajay et.al & Yes & No & Yes & Yes & Yes & \\
\hline
\end{tabular}




\begin{tabular}{lccccc}
$\begin{array}{l}\text { Anand et.al } \\
\text { 2016(41) }\end{array}$ & Yes & Yes & Yes & Yes & Yes \\
$\begin{array}{l}\text { Sharma et.al } \\
\text { 2016(42) }\end{array}$ & Yes & Yes & Yes & Yes & Yes \\
\hline
\end{tabular}

\section{Cohort Study Design}

$80 \%$ of the Cohort studies had active involvement of IT, Data management team while developing the intervention and were either part of the team writing manuscript or dully acknowledged indicating the multisectoral team involved in developing and testing of the initiatives. The pattern of engagement with multisectoral was similar in studies reported before the COVID-19 pandemic and during the COVID-19 pandemic. However, in all the cohort studies assessed, engagement of multiple sectors was not seen amongst $80 \%$ of studies (needs rephrasing).

$65 \%$ of Cohort studies reported adherence to WHO/ ICDS standards for the classification of diseases, however, studies have not mentioned adherence to data interchange standards like HL7.

All the cohort studies assessed have mentioned gap analysis and needs assessment for the development of the initiative. About $60 \%$ mentioned feedback collection from end-users, delivery providers and have mentioned changes made in digital initiative upon receiving feedback.

Overall the average sustainability of Cohort studies on digital health was $40 \%$, and there was no statistically significant difference in overall sustainability score (how has this score been calculated and what is the validity of the tool may be to consider reporting in the form of yes and no) between the studies published Pre-pandemic (25.3\%) and During Pandemic (35.6\%) (p-value 0.45).

Table 4 and Figure 7 presents the study wise assessment score summary and percentage of sustainability scores based on the authors' judgement.

Table 4 - Assessment of Sustainability, Cohort studies 


\begin{tabular}{|c|c|c|c|c|c|c|}
\hline & Author & $\begin{array}{l}\text { Does the } \\
\text { study } \\
\text { involve a } \\
\text { multisectoral } \\
\text { team? }\end{array}$ & $\begin{array}{l}\text { Does the } \\
\text { study } \\
\text { involve } \\
\text { engagement } \\
\text { with sectors } \\
\text { other than } \\
\text { health? }\end{array}$ & $\begin{array}{l}\text { Does the study } \\
\text { mention } \\
\text { adherence to } \\
\text { any standards } \\
\text { of data } \\
\text { components, } \\
\text { data } \\
\text { interchange, } \\
\text { application- } \\
\text { level support? }\end{array}$ & $\begin{array}{l}\text { Does the study } \\
\text { mention } \\
\text { stakeholder } \\
\text { analysis/ } \\
\text { community } \\
\text { needs } \\
\text { assessment/ } \\
\text { with end-users } \\
\text { for the } \\
\text { development of } \\
\text { the initiative? }\end{array}$ & $\begin{array}{l}\text { Does the } \\
\text { study } \\
\text { mention } \\
\text { scope of } \\
\text { collecting } \\
\text { feedback } \\
\text { from the } \\
\text { end- } \\
\text { users? }\end{array}$ \\
\hline $\begin{array}{l}\text { During } \\
\text { COVID-19 } \\
\text { pandemic }\end{array}$ & $\begin{array}{l}\text { Saw et.al } \\
2020(43)\end{array}$ & Yes & Can't Say & No & Yes & Yes \\
\hline $\begin{array}{l}\text { Baroutsout } \\
\text { et.al } \\
2020(44)\end{array}$ & Yes & No & Can't Say & Yes & Yes & \\
\hline $\begin{array}{l}\text { Tyler et.al } \\
2020(45)\end{array}$ & Yes & No & Yes & Yes & Can't Say & \\
\hline $\begin{array}{l}\text { Garg et.al } \\
2020(46)\end{array}$ & Yes & No & Yes & Yes & Yes & \\
\hline $\begin{array}{l}\text { Mahadevan } \\
\text { et.al } \\
\text { 2020(47) }\end{array}$ & No & No & Yes & Yes & No & \\
\hline $\begin{array}{l}\text { Rachmani } \\
\text { et.al } \\
2020(48)\end{array}$ & Yes & No & Yes & Yes & Yes & \\
\hline $\begin{array}{l}\text { Pre COVID- } \\
19 \text { pandemic }\end{array}$ & $\begin{array}{l}\text { Shah } \\
\text { et.al } \\
2019(49)\end{array}$ & Yes & Yes & Can't Say & Yes & Yes \\
\hline $\begin{array}{l}\text { Farnham } \\
\text { et.al } \\
2017(50)\end{array}$ & Yes & No & Yes & Yes & Yes & \\
\hline $\begin{array}{l}\text { Balakrishnan } \\
\text { et.al } 2016 \\
\text { (17) }\end{array}$ & No & No & Yes & Yes & Yes & \\
\hline
\end{tabular}

\section{Cross-Sectional Study}

$25 \%$ of the Cross-Sectional studies had active involvement of IT, Data management team while developing the intervention and were either part of the team writing manuscript or dully acknowledged indicating the multisectoral team involved in developing and testing of the initiatives. The percentage of active involvement of multisectoral team was higher in cross-sectional studies reported during COVID-19 as compared to Pre COVID-19 reported studies. However, amongst $80 \%$ of cross-sectional studies assessed, engagement of multiple sectors was not seen.

$90 \%$ of cross-sectional studies reported during the COVID-19 pandemic reported adherence to WHO/ ICDS standards for the classification of diseases, whereas only $10 \%$ of cross-sectional studies reported pre COVID-19 reported adherence to WHO/ ICDS standards for the classification of diseases. 
$30 \%$ of cross-sectional studies have mentioned gap analysis, needs assessment for the development of the initiative. About $40 \%$ of studies have mentioned feedback collection from end-users, delivery providers and have mentioned changes made in digital initiative upon receiving feedback.

Overall the average sustainability of Cross-Sectional studies on digital health was $40 \%$, and there was a statistically significant difference in overall sustainability score between the studies published Pre-pandemic (45.3\%) and During Pandemic (27.7\%) (p-value 0.002).

Table 5 and Figure 8 presents the study wise assessment score summary and percentage of sustainability scores based on the authors' judgement.

Table 5 - Assessment of Sustainability, Cross-Sectional Study 


\begin{tabular}{|c|c|c|c|c|c|c|}
\hline & Author & $\begin{array}{l}\text { Does the } \\
\text { study } \\
\text { involve a } \\
\text { multisectoral } \\
\text { team? }\end{array}$ & $\begin{array}{l}\text { Does the } \\
\text { study } \\
\text { involve } \\
\text { engagement } \\
\text { with sectors } \\
\text { other than } \\
\text { health? }\end{array}$ & $\begin{array}{l}\text { Does the } \\
\text { study } \\
\text { mention } \\
\text { adherence to } \\
\text { any } \\
\text { standards of } \\
\text { data } \\
\text { components, } \\
\text { data } \\
\text { interchange, } \\
\text { application- } \\
\text { level } \\
\text { support? }\end{array}$ & $\begin{array}{l}\text { Does the } \\
\text { study } \\
\text { mention } \\
\text { stakeholder } \\
\text { analysis/ } \\
\text { community } \\
\text { needs } \\
\text { assessment/ } \\
\text { with end- } \\
\text { users for the } \\
\text { development } \\
\text { of the } \\
\text { initiative? }\end{array}$ & $\begin{array}{l}\text { Does the } \\
\text { study } \\
\text { mention } \\
\text { scope of } \\
\text { collecting } \\
\text { feedback } \\
\text { from the } \\
\text { end- } \\
\text { users? }\end{array}$ \\
\hline $\begin{array}{l}\text { During COVID-19 } \\
\text { pandemic }\end{array}$ & $\begin{array}{l}\text { Ravindran } \\
\text { et.al } \\
2021(51)\end{array}$ & No & No & Yes & Yes & Yes \\
\hline $\begin{array}{l}\text { Ward et.al } \\
2020(52)\end{array}$ & Yes & Yes & Yes & Yes & Yes & \\
\hline $\begin{array}{l}\text { Huang et.al } \\
2020(53)\end{array}$ & No & No & Yes & No & Yes & \\
\hline $\begin{array}{l}\text { Singh et.al } \\
2020(54)\end{array}$ & No & No & Yes & No & Yes & \\
\hline $\begin{array}{l}\text { Vijayasundaram } \\
\text { et.al 2020(55) }\end{array}$ & No & No & Yes & No & Yes & \\
\hline $\begin{array}{l}\text { Xiong et.al } \\
2020(56)\end{array}$ & Yes & Yes & Yes & No & No & \\
\hline Das et.al 2020(57) & No & No & Yes & No & No & \\
\hline $\begin{array}{l}\text { Shenoy et.al } \\
2020(58)\end{array}$ & No & No & No & Yes & Yes & \\
\hline $\begin{array}{l}\text { Charumathi et.al } \\
2020(59)\end{array}$ & Yes & No & Yes & No & No & \\
\hline $\begin{array}{l}\text { Shreshta et.al } \\
2020(60)\end{array}$ & No & No & Yes & No & No & \\
\hline $\begin{array}{l}\text { Chuenphitthayavut } \\
\text { et.al 2020(61) }\end{array}$ & Yes & No & Yes & No & No & \\
\hline $\begin{array}{l}\text { Pre COVID-19 } \\
\text { pandemic }\end{array}$ & $\begin{array}{l}\text { Kogan } \\
\text { et.al } \\
2019(62)\end{array}$ & Yes & No & No & No & No \\
\hline $\begin{array}{l}\text { Dandge et.al } \\
2019(63)\end{array}$ & No & No & No & No & No & \\
\hline $\begin{array}{l}\text { Soni et.al } \\
2018(64)\end{array}$ & No & NO & No & No & No & \\
\hline $\begin{array}{l}\text { Bhatt et.al } \\
2018(65)\end{array}$ & No & No & No & Yes & Yes & \\
\hline $\begin{array}{l}\text { Shah et.al } \\
2018(49)\end{array}$ & Yes & No & No & No & No & \\
\hline Chahar et.al & No & No & Yes & No & No & \\
\hline
\end{tabular}




\begin{tabular}{llllll}
$\begin{array}{l}\text { Birur et.al } \\
2018(67)\end{array}$ & No & No & No & Can't Say & Yes \\
\hline Lee et.al 2018(68) & Yes & No & No & No & Yes \\
\hline Kazi et.al 2017(69) & Yes & No & No & Yes & No \\
$\begin{array}{l}\text { Devasahay et.al } \\
2017(70)\end{array}$ & Yes & No & No & No & No \\
$\begin{array}{l}\text { Lan Hoang et.al } \\
2016(71)\end{array}$ & Can't Say & No & No & No & No \\
\hline
\end{tabular}

\section{Diagnostic studies}

$70 \%$ of the Diagnostic studies had active involvement of IT, Data management team while developing the intervention and were either part of the team writing manuscript or dully acknowledged indicating the multisectoral team involved in developing and testing of the initiatives. The percentage of active involvement of multisectoral team was higher in diagnostic studies reported Pre COVID-19 pandemic as COVID-19 reported studies. However, amongst $95 \%$ of diagnostic studies assessed, engagement of multiple sectors was not seen.

$60 \%$ of Diagnostic studies reported adherence to WHO/ ICDS standards for the classification of diseases, majority of studies reported during the COVID-19 pandemic were able to provide information on adherence to standards

$25 \%$ of Diagnostic studies assessed have mentioned gap analysis, needs assessment for the development of the initiative. About $30 \%$ of studies have mentioned feedback collection from end-users, delivery providers and have mentioned changes made in digital initiative upon receiving feedback.

Overall the average sustainability of Diagnostic studies on digital health was $45 \%$, and there was no statistically significant difference in overall sustainability score between the studies published Pre-pandemic (45\%) and During Pandemic (55\%) (p-value 0.5)

Table 6 and Figure 8 presents the study wise assessment score summary and percentage of sustainability scores based on the authors' judgement.

Table 6- Assessment of Sustainability, Diagnostic Study 


\begin{tabular}{|c|c|c|c|c|c|c|}
\hline & Author & $\begin{array}{l}\text { Does the } \\
\text { study } \\
\text { involve a } \\
\text { multisectoral } \\
\text { team? }\end{array}$ & $\begin{array}{l}\text { Does the } \\
\text { study } \\
\text { involve } \\
\text { engagement } \\
\text { with sectors } \\
\text { other than } \\
\text { health? }\end{array}$ & $\begin{array}{l}\text { Does the } \\
\text { study } \\
\text { mention } \\
\text { adherence to } \\
\text { any } \\
\text { standards of } \\
\text { data } \\
\text { components, } \\
\text { data } \\
\text { interchange, } \\
\text { application- } \\
\text { level } \\
\text { support? }\end{array}$ & $\begin{array}{l}\text { Does the } \\
\text { study } \\
\text { mention } \\
\text { stakeholder } \\
\text { analysis/ } \\
\text { community } \\
\text { needs } \\
\text { assessment/ } \\
\text { with end- } \\
\text { users for the } \\
\text { development } \\
\text { of the } \\
\text { initiative? }\end{array}$ & $\begin{array}{l}\text { Does the } \\
\text { study } \\
\text { mention } \\
\text { scope of } \\
\text { collecting } \\
\text { feedback } \\
\text { from the } \\
\text { end- } \\
\text { users? }\end{array}$ \\
\hline $\begin{array}{l}\text { During COVID-19 } \\
\text { pandemic }\end{array}$ & $\begin{array}{l}\text { Rajvanshi } \\
\text { et.al } \\
2021(72)\end{array}$ & Yes & Yes & Yes & Can't Say & Yes \\
\hline $\begin{array}{l}\text { Kannure et.al } \\
2021(73)\end{array}$ & No & No & No & No & No & \\
\hline $\begin{array}{l}\text { Satgunam et.al } \\
2020(74)\end{array}$ & No & No & Yes & No & No & \\
\hline $\begin{array}{l}\text { Tham et.al } \\
2021(75)\end{array}$ & Yes & No & Yes & No & No & \\
\hline $\begin{array}{l}\text { Praveen Raj et.al } \\
2020(76)\end{array}$ & Yes & No & Yes & No & No & \\
\hline $\begin{array}{l}\text { Bulten et.al } \\
2020(77)\end{array}$ & No & No & Yes & Yes & Yes & \\
\hline $\begin{array}{l}\text { Dan Milea et.al } \\
2020(78)\end{array}$ & No & No & Yes & Yes & Yes & \\
\hline $\begin{array}{l}\text { Mondal et.al } \\
2020(80)\end{array}$ & No & No & Yes & No & Yes & \\
\hline $\begin{array}{l}\text { Tahsin kurc et.al } \\
2020(79)\end{array}$ & Yes & No & Yes & No & No & \\
\hline $\begin{array}{l}\text { Pre COVID-19 } \\
\text { pandemic }\end{array}$ & $\begin{array}{l}\text { Shantharam } \\
\text { et.al } \\
2019(80)\end{array}$ & Yes & No & No & Yes & Yes \\
\hline $\begin{array}{l}\text { Sumsum Sunny } \\
\text { et.al } 2019(82)\end{array}$ & Yes & No & No & No & No & \\
\hline $\begin{array}{l}\text { Muller et.al } \\
2019(81)\end{array}$ & Yes & No & Yes & No & No & \\
\hline $\begin{array}{l}\text { Vorakulpipat } \\
\text { et.al } 2019(82)\end{array}$ & Yes & No & No & No & No & \\
\hline $\begin{array}{l}\text { Beane et.al } \\
2019(83)\end{array}$ & Yes & No & No & Yes & Yes & \\
\hline $\begin{array}{l}\text { Ramkumar et.al } \\
2018(84)\end{array}$ & Yes & No & No & Yes & Yes & \\
\hline $\begin{array}{l}\text { Kumar et.al } \\
2018(85)\end{array}$ & Yes & No & Yes & No & No & \\
\hline
\end{tabular}




\begin{tabular}{|c|c|c|c|c|c|}
\hline $\begin{array}{l}\text { Koesoemadinata } \\
\text { et.al 2018(86) }\end{array}$ & Yes & No & Yes & No & No \\
\hline $\begin{array}{l}\text { Kimberly M et.al } \\
2018(87)\end{array}$ & Yes & No & Yes & Yes & Yes \\
\hline $\begin{array}{l}\text { Maity et.al } \\
2017(88)\end{array}$ & Yes & No & Yes & No & No \\
\hline $\begin{array}{l}\text { Malhotra et.al } \\
\text { 2017(90) }\end{array}$ & No & No & No & Yes & Yes \\
\hline
\end{tabular}

\section{Pilot Studies and Development studies}

We used the definition given by Stewart PW(89) for Pilot and Development studies as "small study to test research protocols, data collection instruments, sample recruitment strategies, and other research techniques in preparation for a larger study" however pilot randomized studies were included in experimental studies.

75\% of the Pilot and Development studies had active involvement of IT, Data management team while developing the intervention and were either part of the team writing manuscript or dully acknowledged indicating the multisectoral team involved in developing and testing of the initiatives. The percentage of active involvement of multisectoral team was similar for studies report Pre COVID-19 pandemic and during COVID-19 reported studies. However, amongst $95 \%$ of diagnostic studies assessed, engagement of multiple sectors was not seen.

$80 \%$ of Pilot and Development studies reported adherence to WHO/ ICDS standards for the classification of diseases.

$50 \%$ of Pilot and Development studies assessed have mentioned gap analysis, needs assessment for the development of the initiative. Similarly, $50 \%$ of studies have mentioned feedback collection from end-users, delivery providers and have mentioned changes made in digital initiative upon receiving feedback.

Overall the average sustainability of Pilot and Development studies on digital health was $65 \%$, and there was no statistically significant difference in overall sustainability score between the studies published Pre-pandemic (56\%) and During Pandemic (63\%) (p-value 0.28)

Table 7 and Figure 9 presents the study wise assessment score summary and percentage of sustainability scores based on the authors judgement

Table 7- Assessment of Sustainability, Pilot and Development studies 


\begin{tabular}{|c|c|c|c|c|c|c|}
\hline & Author & $\begin{array}{l}\text { Does the } \\
\text { study } \\
\text { involve a } \\
\text { multisectoral } \\
\text { team? }\end{array}$ & $\begin{array}{l}\text { Does the } \\
\text { study } \\
\text { involve } \\
\text { engagement } \\
\text { with sectors } \\
\text { other than } \\
\text { health? }\end{array}$ & $\begin{array}{l}\text { Does the study } \\
\text { mention } \\
\text { adherence to } \\
\text { any standards } \\
\text { of data } \\
\text { components, } \\
\text { data } \\
\text { interchange, } \\
\text { application-level } \\
\text { support? }\end{array}$ & $\begin{array}{l}\text { Does the study } \\
\text { mention } \\
\text { stakeholder } \\
\text { analysis/ } \\
\text { community needs } \\
\text { assessment/ with } \\
\text { end-users for the } \\
\text { development of } \\
\text { the initiative? }\end{array}$ & $\begin{array}{l}\text { Does the } \\
\text { study } \\
\text { mention } \\
\text { scope of } \\
\text { collecting } \\
\text { feedback } \\
\text { from the } \\
\text { end- } \\
\text { users? }\end{array}$ \\
\hline $\begin{array}{l}\text { During } \\
\text { COVID-19 } \\
\text { pandemic }\end{array}$ & $\begin{array}{l}\text { Bafna } \\
\text { et..al } \\
2020(90)\end{array}$ & No & No & Yes & No & No \\
\hline $\begin{array}{l}\text { Nikita et.al } \\
2020(91)\end{array}$ & No & No & No & Yes & Yes & \\
\hline $\begin{array}{l}\text { Hegde } \\
\text { et.al } \\
2020(92)\end{array}$ & Yes & No & No & No & No & \\
\hline $\begin{array}{l}\text { AnLee } \\
\text { et.al } \\
2020(93)\end{array}$ & Yes & No & Yes & No & No & \\
\hline $\begin{array}{l}\text { Misra et.al } \\
2020(94)\end{array}$ & Yes & No & Yes & Yes & Yes & \\
\hline $\begin{array}{l}\text { Thornber } \\
\text { et.al } \\
2020(95)\end{array}$ & Yes & No & No & Yes & Yes & \\
\hline $\begin{array}{l}\text { Pre } \\
\text { COVID-19 } \\
\text { pandemic }\end{array}$ & $\begin{array}{l}\text { Ayyanar } \\
\text { et.al } \\
2019(96)\end{array}$ & Yes & No & Yes & No & No \\
\hline $\begin{array}{l}\text { Ahmed } \\
\text { et.al } \\
2019(97)\end{array}$ & No & No & Yes & No & No & \\
\hline $\begin{array}{l}\text { Devraj } \\
\text { et.al } \\
2019(98)\end{array}$ & Yes & No & Yes & Yes & Yes & \\
\hline $\begin{array}{l}\text { Drusbosky } \\
\text { et.al } \\
2019(99)\end{array}$ & Yes & No & Yes & No & No & \\
\hline $\begin{array}{l}\text { Jain et.al } \\
2019(100)\end{array}$ & Yes & No & No & Yes & Yes & \\
\hline $\begin{array}{l}\text { Verma } \\
\text { et.al } \\
\text { 2018(101) }\end{array}$ & No & Yes & Yes & No & No & \\
\hline $\begin{array}{l}\text { Rao et.al } \\
2018 \\
(102)\end{array}$ & Yes & No & Yes & Yes & Yes & \\
\hline $\begin{array}{l}\text { Aggarwal } \\
\text { et.al } \\
2018(103)\end{array}$ & Yes & No & Yes & No & No & \\
\hline
\end{tabular}


$\begin{array}{lllll}\text { Devraj } & \text { Yes } & \text { No } & \text { Yes } & \text { Yes }\end{array}$

The assessment of sustainability analysis indicates

- Experimental studies and Cohort studies had incorporated factors contributing to sustainability and involvement of teams, sectors, feedback was reported across a majority of studies irrespective of Pre COVID19 pandemic or During the COVID-19 pandemic

- Cross-Sectional studies, conducted during pandemic improved on parameters of assessment of sustainability and the difference between sustainability assessment Pre COVID-19 Pandemic and During COVID-19 pandemic was statistically significant

- Diagnostic Studies and Pilot and Development studies had incorporated limited factors contributing to sustainability irrespective of Pre COVID-19 pandemic or During the COVID-19 pandemic

\section{Discussion}

This study is the first to our knowledge, which has systematically analyzed and presented evidence from the sustainability perspective of digital health research initiative across South Asia. A systematic review by Bassi et. al(108) in 2018 looked at the current status and future perspectives of mHealth from Health Systems perspectives, the review highlighted the poor quality of evidence generated through mHealth research. Another review by Bassi et.al (109) in 2020 presented the review COVID-19 related mobile apps and highlight gaps to inform the development of future mHealth initiatives, wherein the functionality of mobile applications was assessed to adjunct risk assessment efforts. Another systematic review by Kondylakis et. al(110) raised concerns about the quality of research studies published on the development and implementation of COVID-19 Mobile applications.

The COVID-19 pandemic saw a huge increase in research of digital health initiatives, our study hypothesis was based on the increased number that has affected the sustainability of the research initiatives; and the intrinsic factors of research initiatives like multisectoral involvement, gap analysis, stakeholder engagement.

In this paper, we descriptively analyzed the impact of the COVID-19 pandemic on the volume of research in digital health. To ascertain the sustainability, we searched for standardized tools available for sustainability assessment, however, the tools didn't suit the needs presented in this study. This led to the development of a simple tool for the assessment of sustainability. The assessment of sustainability was undertaken for 87 articles and the tool can determine intrinsic sustainability factors and give summary estimates on how well the authors incorporate sustainability in digital health research.

In our study we found the number of digital health interventions research increased significantly during the COVID19 pandemic, and most authors took initiative to have oversight on the sustainability of their digital health initiatives. Contrary to our hypothesis, the sustainability score of cross-sectional studies was higher for studies published during the COVID-19 pandemic as compared to studies published before the COVID-19 pandemic.

From our study its is clear that choice of digital tool, disease and study design vary highly based on study objectives and research, however, the patterns presented over five years show higher research interest in Ophthalmic Disorders, Health Systems Strengthening, while Health Information Exchange tools have been 
exclusively used. The underlying reasons can be further explored and taken up for further research and help derive recommendations at a policy level.

\section{Conclusion And Recommendation}

We conclude that the COVID-19 pandemic had a silver lining and it positively impacted Digital health research, with improving the number of research initiatives undertaken from South Asia and with researchers able to develop a long term vision for digital health initiatives.

The momentum and interest in digital health gained due to the COVID-19 pandemic should be sustained postpandemic world and with our sustainability analysis, there is certain confidence about the researchers able to develop a vision to sustain the initiative, much however depends on extrinsic factors like availability of skilled manpower, conducive policy environment, access to internet and hardware amongst target population.

\section{References}

1. Global strategy on digital health 2020-2025 [Internet]. [cited 2021 Apr 5]. Available from: https://www.who.int/docs/default-source/documents/gs4dhdaa2a9f352b0445bafbc79ca799dce4d.pdf? sfvrsn=f112ede5_38

2. Ammenwerth E, Iller C, Mahler C. IT-adoption and the interaction of task, technology and individuals: a fit framework and a case study. BMC Med Inform Decis Mak. 2006 Jan 9;6(1):3.

3. Ye J. The Role of Health Technology and Informatics in a Global Public Health Emergency: Practices and Implications From the COVID-19 Pandemic. JMIR Med Inform. 2020 Jul 14;8(7):e19866.

4. Roberton T, Carter ED, Chou VB, Stegmuller AR, Jackson BD, Tam Y, et al. Early estimates of the indirect effects of the COVID-19 pandemic on maternal and child mortality in low-income and middle-income countries: a modelling study. Lancet Glob Health. 2020 May;S2214109X20302291.

5. Chetterje P. Gaps in India's preparedness for COVID-19 control. Lancet Infect Dis. 2020 May;20(5):544.

6. Fore HH. A wake-up call: COVID-19 and its impact on children's health and wellbeing. Lancet Glob Health. 2020 May;S2214109X20302382.

7. Brown RB. Public health lessons learned from biases in coronavirus mortality overestimation. Disaster Med Public Health Prep. 2020 Aug 12;1-24.

8. Sustainability assessment methods and tools to support decision-making in the process industries | SAMT Project | H2020 | CORDIS | European Commission [Internet]. [cited 2021 Apr 6]. Available from: https://cordis.europa.eu/project/id/636727

9. Taisch M, Sadr V, May G, Stahl B. Sustainability Assessment Tools - State of Research and Gap Analysis. In: Prabhu V, Taisch M, Kiritsis D, editors. Advances in Production Management Systems Sustainable Production and Service Supply Chains [Internet]. Berlin, Heidelberg: Springer Berlin Heidelberg; 2013 [cited 2021 Apr 6]. p. 426-34. (IFIP Advances in Information and Communication Technology; vol. 415). Available from: http://link.springer.com/10.1007/978-3-642-41263-9_53

10. Hallin A, Karrbom-Gustavsson T, editors. Organizational Communication and Sustainable Development: ICTs for Mobility [Internet]. IGI Global; 2010 [cited 2021 Apr 6]. Available from: http://services.igiglobal.com/resolvedoi/resolve.aspx?doi=10.4018/978-1-60566-822-2 
11. Villeneuve C, Tremblay D, Riffon O, Lanmafankpotin GY, Bouchard S. A Systemic Tool and Process for Sustainability Assessment. Sustainability. 2017 Oct;9(10):1909.

12. PSAT [Internet]. PSAT/CSAT. [cited 2021 Apr 6]. Available from: https://sustaintool.org/psat/

13. CSAT [Internet]. PSAT/CSAT. [cited 2021 Apr 6]. Available from: https://sustaintool.org/csat/

14. Safety I of M (US) C on DS for P, Aspden P, Corrigan JM, Wolcott J, Erickson SM. Health Care Data Standards [Internet]. Patient Safety: Achieving a New Standard for Care. National Academies Press (US); 2004 [cited 2021 Apr 6]. Available from: https://www.ncbi.nlm.nih.gov/books/NBK216088/

15. Hofman W, Rajagopal M. A Technical Framework for Data Sharing. J Theor Appl Electron Commer Res. 2014 Sep;9(3):45-58.

16. Deldar K, Bahaadinbeigy K, Tara SM. Teleconsultation and Clinical Decision Making: a Systematic Review. Acta Inform Medica. 2016 Jul 16;24(4):286-92.

17. Balakrishnan K, Honavar V. Intelligent Diagnosis Systems. J Intell Syst [Internet]. 1998 Jan [cited 2021 Apr 8];8(3-4). Available from: https://www.degruyter.com/document/doi/10.1515/JISYS.1998.8.3-4.239/html

18. Demiris G, Iribarren SJ, Sward K, Lee S, Yang R. Patient generated health data use in clinical practice: A systematic review. Nurs Outlook. 2019 Aug;67(4):311-30.

19. Predictive Analytics [Internet]. 2021 [cited 2021 Apr 8]. Available from: https://www.ibm.com/analytics/predictive-analytics

20. Sim I, Gorman P, Greenes RA, Haynes RB, Kaplan B, Lehmann H, et al. Clinical Decision Support Systems for the Practice of Evidence-based Medicine. J Am Med Inform Assoc. 2001 Nov 1;8(6):527-34.

21. Ristevski B, Chen M. Big Data Analytics in Medicine and Healthcare. J Integr Bioinforma [Internet]. 2018 May 10 [cited 2021 Apr 8];15(3). Available from: https://www.ncbi.nlm.nih.gov/pmc/articles/PMC6340124/

22. Oleske DM. Screening and Surveillance for Promoting Population Health. Epidemiol Deliv Health Care Serv. 2009 Apr 2;131-50.

23. Li Q. Overview of Data Visualization. Embodying Data. 2020 Jun 20;17-47.

24. WHO | Contact tracing [Internet]. WHO. World Health Organization; [cited 2021 Apr 8]. Available from: https://www.who.int/csr/resources/publications/ebola/contact-tracing-guidelines/en/

25. Swendeman D, Fehrenbacher AE, Roy S, Ray P, Sumstine S, Scheffler A, et al. A pilot randomized controlled trial (RCT) of daily versus weekly interactive voice response calls to support adherence among antiretroviral treatment patients in India. mHealth. 2020;6:35.

26. Shekhawat NS, Niziol LM, Sharma SS, Joseph S, Robin AL, Gillespie BW, et al. The Utility of Routine Fundus Photography Screening for Posterior Segment Disease: A Stepped-wedge, Cluster-randomized Trial in South India. Ophthalmology. 2020 Nov 27;

27. Johri M, Chandra D, Kone KG, Sylvestre M-P, Mathur AK, Harper S, et al. Social and Behavior Change Communication Interventions Delivered Face-to-Face and by a Mobile Phone to Strengthen Vaccination Uptake and Improve Child Health in Rural India: Randomized Pilot Study. JMIR MHealth UHealth. 2020 Sep 21;8(9):e20356.

28. Suryavanshi N, Kadam A, Kanade S, Gupte N, Gupta A, Bollinger R, et al. Acceptability and feasibility of a behavioral and mobile health intervention (COMBIND) shown to increase uptake of prevention of mother to child transmission (PMTCT) care in India. BMC Public Health. 2020 May 24;20(1):752.

29. Nanditha A, Thomson H, Susairaj P, Srivanichakorn W, Oliver N, Godsland IF, et al. A pragmatic and scalable strategy using mobile technology to promote sustained lifestyle changes to prevent type 2 diabetes in India 
and the UK: a randomised controlled trial. Diabetologia. 2020 Mar;63(3):486-96.

30. Modi D, Dholakia N, Gopalan R, Venkatraman S, Dave K, Shah S, et al. mHealth intervention "ImTeCHO" to improve delivery of maternal, neonatal, and child care services-A cluster-randomized trial in tribal areas of Gujarat, India. PLoS Med. 2019 Oct;16(10):e1002939.

31. Huang Z, Tan E, Lum E, Sloot P, Boehm BO, Car J. A Smartphone App to Improve Medication Adherence in Patients With Type 2 Diabetes in Asia: Feasibility Randomized Controlled Trial. JMIR MHealth UHealth [Internet]. 2019 Sep 12 [cited 2021 Apr 3];7(9). Available from:

https://www.ncbi.nlm.nih.gov/pmc/articles/PMC6746066/

32. Joseph S, Kim R, Ravindran RD, Fletcher AE, Ravilla TD. Effectiveness of Teleretinal Imaging-Based Hospital Referral Compared With Universal Referral in Identifying Diabetic Retinopathy: A Cluster Randomized Clinical Trial. JAMA Ophthalmol. 2019 Jul 1;137(7):786-92.

33. Sarna A, Saraswati LR, Okal J, Matheka J, Owuor D, Singh RJ, et al. Cell Phone Counseling Improves Retention of Mothers With HIV Infection in Care and Infant HIV Testing in Kisumu, Kenya: A Randomized Controlled Study. Glob Health Sci Pract. 2019 Jun;7(2):171-88.

34. Gross R, Ritz J, Hughes MD, Salata R, Mugyenyi P, Hogg E, et al. Two-way mobile phone intervention compared with standard-of-care adherence support after second-line antiretroviral therapy failure: a multinational, randomised controlled trial. Lancet Digit Health. 2019 May;1(1):e26-34.

35. Jiang Y, Jiao N, Nguyen HD, Lopez V, Wu VX, Kowitlawakul Y, et al. Effect of a mHealth programme on coronary heart disease prevention among working population in Singapore: A single group pretest-post-test design. J Adv Nurs. 2019 Sep;75(9):1922-32.

36. Peiris D, Praveen D, Mogulluru K, Ameer MA, Raghu A, Li Q, et al. SMARThealth India: A stepped-wedge, cluster randomised controlled trial of a community health worker managed mobile health intervention for people assessed at high cardiovascular disease risk in rural India. PloS One. 2019;14(3):e0213708.

37. R R, R A, K B, M Y, C K, M R, et al. Evaluation of computer-based retinopathy of prematurity (ROP) education for ophthalmology residents: a randomized, controlled, multicenter study. J AAPOS Off Publ Am Assoc Pediatr Ophthalmol Strabismus [Internet]. 2019 Apr [cited 2021 Apr 4];23(2). Available from:

https://pubmed.ncbi.nlm.nih.gov/30885809/

38. Prabhakaran D, Jha D, Prieto-Merino D, Roy A, Singh K, Ajay VS, et al. Effectiveness of an mHealth-Based Electronic Decision Support System for Integrated Management of Chronic Conditions in Primary Care: The mWellcare Cluster-Randomized Controlled Trial. Circulation. 2018 Nov 10;

39. Zhang H, Jiang Y, Nguyen HD, Poo DCC, Wang W. The effect of a smartphone-based coronary heart disease prevention (SBCHDP) programme on awareness and knowledge of CHD, stress, and cardiac-related lifestyle behaviours among the working population in Singapore: a pilot randomised controlled trial. Health Qual Life Outcomes. 2017 Mar 14;15(1):49.

40. Ajay VS, Jindal D, Roy A, Venugopal V, Sharma R, Pawar A, et al. Development of a Smartphone-Enabled Hypertension and Diabetes Mellitus Management Package to Facilitate Evidence-Based Care Delivery in Primary Healthcare Facilities in India: The mPower Heart Project. J Am Heart Assoc. 2016 Dec 21;5(12).

41. Anand SS, Samaan Z, Middleton C, Irvine J, Desai D, Schulze KM, et al. A Digital Health Intervention to Lower Cardiovascular Risk: A Randomized Clinical Trial. JAMA Cardiol. 2016 Aug 1;1(5):601-6.

42. Sharma P, Rani MU. Effect of Digital Nutrition Education Intervention on the Nutritional Knowledge Levels of Information Technology Professionals. Ecol Food Nutr. 2016 Oct;55(5):442-55. 
43. Saw YE, Tan EY-Q, Liu JS, Liu JC. Predicting Public Uptake of Digital Contact Tracing During the COVID-19 Pandemic: Results From a Nationwide Survey in Singapore. J Med Internet Res. 2021 Feb 3;23(2):e24730.

44. Baroutsou V, Hatz C, Blanke U, Haile SR, Fehr J, Neumayr A, et al. TOURIST2 - Tracking of urgent risks in swiss travellers to the 6 main travel destinations - Feasibility and ethical considerations of a smartphone applicationbased study. Travel Med Infect Dis. 2021 Feb;39:101912.

45. Rim TH, Lee G, Kim Y, Tham Y-C, Lee CJ, Baik SJ, et al. Prediction of systemic biomarkers from retinal photographs: development and validation of deep-learning algorithms. Lancet Digit Health. 2020 Oct;2(10):e526-36.

46. Garg PR, Uppal L, Mehra S, Mehra D. Mobile Health App for Self-Learning on HIV Prevention Knowledge and Services Among a Young Indonesian Key Population: Cohort Study. JMIR MHealth UHealth. 2020 Sep 8;8(9):e17646.

47. Mahadevan J, Shukla L, Chand P, Komaromy M, Murthy P, Arora S. Innovative virtual mentoring using the Extension for Community Healthcare Outcomes model for primary care providers for the management of alcohol use disorders. Indian J Med Res. 2020;151(6):609.

48. Rachmani E, Lin M-C, Hsu CY, Jumanto J, Iqbal U, Shidik GF, et al. The implementation of an integrated eleprosy framework in a leprosy control program at primary health care centers in Indonesia. Int J Med Inf. 2020 Aug;140:104155.

49. Shah S, Shinde A, Anand A, Modi D, Desai G, Bhatt H, et al. The role of an mHealth intervention in improving knowledge and skills of accredited social health activists in tribal areas of Gujarat, India: a nested study within an implementation research trial. Acta Paediatr Oslo Nor 1992. 2018 Dec;107 Suppl 471:72-9.

50. Farnham A, Röösli M, Blanke U, Stone E, Hatz C, Puhan MA. Streaming data from a smartphone application: A new approach to mapping health during travel. Travel Med Infect Dis. 2018 Feb;21:36-42.

51. Ravindran M, Segi A, Mohideen S, Allapitchai F, Rengappa R. Impact of teleophthalmology during COVID-19 lockdown in a tertiary care center in South India. Indian J Ophthalmol. 2021 Mar;69(3):714-8.

52. Ward VC, Raheel H, Weng Y, Mehta KM, Dutt P, Mitra R, et al. Impact of mHealth interventions for reproductive, maternal, newborn and child health and nutrition at scale: BBC Media Action and the Ananya program in Bihar, India. J Glob Health. 2020 Dec;10(2):021005.

53. Huang Z, Guo H, Lee Y-M, Ho EC, Ang H, Chow A. Performance of Digital Contact Tracing Tools for COVID-19 Response in Singapore: Cross-Sectional Study. JMIR MHealth UHealth. 2020 Oct 29;8(10):e23148.

54. Singh G, Kapoor S, Bansal V, Grewal M, Singh B, Goyal A, et al. Active surveillance with telemedicine in patients on anticoagulants during the national lockdown (COVID-19 phase) and comparison with pre-COVID-19 phase. Egypt Heart J EHJ Off Bull Egypt Soc Cardiol. 2020 Oct 16;72(1):70.

55. Vijayasundaram S, Karthikeyan P, Mehta SD. Proficiency of virtual follow-up amongst tinnitus patients who underwent intratympanic steroid therapy amidst COVID 19 pandemic. Am J Otolaryngol. 2020 Dec;41(6):102680.

56. Xiong J, Hswen Y, Naslund JA. Digital Surveillance for Monitoring Environmental Health Threats: A Case Study Capturing Public Opinion from Twitter about the 2019 Chennai Water Crisis. Int J Environ Res Public Health. 2020 Jul 14;17(14).

57. Das JK, Salam RA, Saeed M, Kazmi FA, Bhutta ZA. Effectiveness of Interventions for Managing Acute Malnutrition in Children under Five Years of Age in Low-Income and Middle-Income Countries: A Systematic Review and Meta-Analysis. Nutrients. 2020 Jan 1;12(1):116.

Page 23/34 
58. Shenoy P, Ahmed S, Paul A, Skaria TG, Joby J, Alias B. Switching to teleconsultation for rheumatology in the wake of the COVID-19 pandemic: feasibility and patient response in India. Clin Rheumatol. 2020 May 30;1-6.

59. Sabanayagam C, Xu D, Ting DSW, Nusinovici S, Banu R, Hamzah H, et al. A deep learning algorithm to detect chronic kidney disease from retinal photographs in community-based populations. Lancet Digit Health. 2020 Jun;2(6):e295-302.

60. Shrestha R, Lim SH, Altice FL, Copenhaver M, Wickersham JA, Saifi R, et al. Use of Smartphone to Seek Sexual Health Information Online Among Malaysian Men Who Have Sex with Men (MSM): Implications for mHealth Intervention to Increase HIV Testing and Reduce HIV Risks. J Community Health. 2020 Feb;45(1):10-9.

61. Chuenphitthayavut K, Zihuang T, Zhu T. The prediction of behavioral intention to use online mental health interventions. PsyCh J. 2020 Jun;9(3):370-82.

62. Kogan NE, Bolon I, Ray N, Alcoba G, Fernandez-Marquez JL, Müller MM, et al. Wet Markets and Food Safety: TripAdvisor for Improved Global Digital Surveillance. JMIR Public Health Surveill. 2019 Apr 1;5(2):e11477.

63. Dandge S, Jeemon P, Reddy PS. Technology enabled non-physician health workers extending telemedicine to rural homes to control hypertension and diabetes (TETRA): A pre-post demonstration project in Telangana, India. PloS One. 2019;14(2):e0211551.

64. Soni A, Karna S, Fahey N, Sanghai S, Patel H, Raithatha S, et al. Age-and-sex stratified prevalence of atrial fibrillation in rural Western India: Results of SMART-India, a population-based screening study. Int J Cardiol. 2019 Apr 1;280:84-8.

65. Bhatt S, Isaac R, Finkel M, Evans J, Grant L, Paul B, et al. Mobile technology and cancer screening: Lessons from rural India. J Glob Health. 2018 Dec;8(2):020421.

66. Chahar P, Mohanty VR, Aswini YB. Designing and validation of text messages for $m$-Health intervention for tobacco cessation and management. Indian J Cancer. 2018 Dec;55(4):390-3.

67. Birur NP, Patrick S, Bajaj S, Raghavan S, Suresh A, Sunny SP, et al. A Novel Mobile Health Approach to Early Diagnosis of Oral Cancer. J Contemp Dent Pract. 2018 Sep 1;19(9):1122-8.

68. Lee HY, Kim JY, Na KY, Park HY, Han J, Pak Y, et al. The role of telehealth counselling with mobile selfmonitoring on blood pressure reduction among overseas Koreans with high blood pressure in Vietnam. J Telemed Telecare. 2019 May;25(4):241-8.

69. Kazi DS, Greenough PG, Madhok R, Heerboth A, Shaikh A, Leaning J, et al. Using mobile technology to optimize disease surveillance and healthcare delivery at mass gatherings: a case study from India's Kumbh Mela. J Public Health Oxf Engl. 2017 Sep 1;39(3):616-24.

70. Devasahay SR, Karpagam S, Ma NL. Predicting appointment misses in hospitals using data analytics. mHealth. 2017 Apr 17;3:12-12.

71. Vu LTH, Nguyen NTK, Tran HTD, Muhajarine N. mHealth information for migrants: an e-health intervention for internal migrants in Vietnam. Reprod Health. 2016 May 14;13(1):55.

72. Rajvanshi H, Jain Y, Kaintura N, Soni C, Chandramohan R, Srinivasan R, et al. A comprehensive mobile application tool for disease surveillance, workforce management and supply chain management for Malaria Elimination Demonstration Project. Malar J. 2021 Feb 16;20(1):91.

73. Kannure M, Hegde A, Khungar-Pathni A, Sharma B, Scuteri A, Neupane D, et al. Phone calls for improving blood pressure control among hypertensive patients attending private medical practitioners in India: Findings from Mumbai hypertension project. J Clin Hypertens Greenwich Conn. 2021 Feb 16; 
74. Satgunam P, Thakur M, Sachdeva V, Reddy S, Rani PK. Validation of visual acuity applications for teleophthalmology during COVID-19. Indian J Ophthalmol. 2021 Feb 1;69(2):385.

75. Tham Y-C, Anees A, Zhang L, Goh JHL, Rim TH, Nusinovici S, et al. Referral for disease-related visual impairment using retinal photograph-based deep learning: a proof-of-concept, model development study. Lancet Digit Health. 2021 Jan 1;3(1):e29-40.

76. Praveen D, Patel A, McMahon S, Prabhakaran D, Clifford GD, Maulik PK, et al. A multifaceted strategy using mobile technology to assist rural primary healthcare doctors and frontline health workers in cardiovascular disease risk management: protocol for the SMARTHealth India cluster randomised controlled trial. Implement Sci IS. 2013 Nov 25;8:137.

77. Bulten W, Balkenhol M, Belinga J-JA, Brilhante A, Çakır A, Egevad L, et al. Artifıcial intelligence assistance significantly improves Gleason grading of prostate biopsies by pathologists. Mod Pathol Off J U S Can Acad Pathol Inc. 2021 Mar;34(3):660-71.

78. Milea D, Najjar RP, Jiang Z, Ting D, Vasseneix C, Xu X, et al. Artificial Intelligence to Detect Papilledema from Ocular Fundus Photographs. N Engl J Med. 2020 Apr 30;382(18):1687-95.

79. Kurc T, Bakas S, Ren X, Bagari A, Momeni A, Huang Y, et al. Segmentation and Classification in Digital Pathology for Glioma Research: Challenges and Deep Learning Approaches. Front Neurosci [Internet]. 2020 Feb 21 [cited 2021 Apr 3];14. Available from: https://www.ncbi.nlm.nih.gov/pmc/articles/PMC7046596/

80. Baliga BS, Jain A, Koduvattat N, Kumar BGP, Kumar M, Kumar A, et al. Indigenously developed digital handheld Android-based Geographic Information System (GIS)-tagged tablets (TABs) in malaria elimination programme in Mangaluru city, Karnataka, India. Malar J. 2019 Dec 26;18(1):444.

81. Müller AM, Wang NX, Yao J, Tan CS, Low ICC, Lim N, et al. Heart Rate Measures From Wrist-Worn Activity Trackers in a Laboratory and Free-Living Setting: Validation Study. JMIR MHealth UHealth [Internet]. 2019 Oct 2 [cited 2021 Apr 8];7(10). Available from: https://www.ncbi.nlm.nih.gov/pmc/articles/PMC6777285/

82. Vorakulpipat C, Rattanalerdnusorn E, Sirapaisan S, Savangsuk V, Kasisopha N. A Mobile-Based Patient-Centric Passive System for Guiding Patients Through the Hospital Workflow: Design and Development. JMIR MHealth UHealth. 2019 Jul 22;7(7):e14779.

83. Beane A, De Silva AP, Athapattu PL, Jayasinghe S, Abayadeera AU, Wijerathne M, et al. Addressing the information deficit in global health: lessons from a digital acute care platform in Sri Lanka. BMJ Glob Health [Internet]. 2019 Jan 29 [cited 2021 Apr 4];4(1). Available from:

https://www.ncbi.nlm.nih.gov/pmc/articles/PMC6352842/

84. Ramkumar V, Rajendran A, Nagarajan R, Balasubramaniyan S, Suresh DK. Identification and Management of Middle Ear Disorders in a Rural Cleft Care Program: A Telemedicine Approach. Am J Audiol. 2018 Nov 19;27(3S):455-61.

85. Kumar SN, Lenin Fred A, Sebastin Varghese P. Compression of CT Images using Contextual Vector Quantization with Simulated Annealing for Telemedicine Application. J Med Syst. 2018 Oct 2;42(11):218.

86. Koesoemadinata RC, Kranzer K, Livia R, Susilawati N, Annisa J, Soetedjo NNM, et al. Computer-assisted chest radiography reading for tuberculosis screening in people living with diabetes mellitus. Int $\mathrm{J}$ Tuberc Lung Dis Off J Int Union Tuberc Lung Dis. 2018 Sep 1;22(9):1088-94.

87. Fornace KM, Surendra H, Abidin TR, Reyes R, Macalinao MLM, Stresman G, et al. Use of mobile technologybased participatory mapping approaches to geolocate health facility attendees for disease surveillance in low resource settings. Int J Health Geogr. 2018 Jun 18;17(1):21. 
88. Maity M, Dhane D, Mungle T, Maiti AK, Chakraborty C. Web-Enabled Distributed Health-Care Framework for Automated Malaria Parasite Classification: an E-Health Approach. J Med Syst. 2017 Oct 26;41(12):192.

89. Stewart PW. Small or pilot study, GCRC protocols which propose "pilot studies". Cincinnati Child Hosp Med Cent.

90. Bafna RK, Beniwal A, Kalra N, Lata S, Asif MI, Sharma N. Use of 'U-shaped tool for follow up of corneal ulcer cases in the COVID-19 pandemic. Indian J Ophthalmol. 2020 Oct 1;68(10):2199.

91. Pandey N, Srivastava RM, Kumar G, Katiyar V, Agrawal S. Teleconsultation at a tertiary care government medical university during COVID-19 Lockdown in India - A pilot study. Indian J Ophthalmol. 2020 Jul;68(7):1381-4.

92. Hegde A, Masthi R, Krishnappa D. Hyperlocal Postcode Based Crowdsourced Surveillance Systems in the COVID-19 Pandemic Response. Front Public Health [Internet]. 2020 Jun 9 [cited 2021 Apr 2];8. Available from: https://www.ncbi.nlm.nih.gov/pmc/articles/PMC7296149/

93. Lee H-A, Kung H-H, Udayasankaran JG, Kijsanayotin B, B Marcelo A, Chao LR, et al. An Architecture and Management Platform for Blockchain-Based Personal Health Record Exchange: Development and Usability Study. J Med Internet Res. 2020 Jun 9;22(6):e16748.

94. Misra N, Khanna RC, Mettla AL, Marmamula S, Rathi VM, Das AV. Role of teleophthalmology to manage anterior segment conditions in vision centres of south India: EyeSmart study-I. Indian J Ophthalmol. 2020 Feb;68(2):362-7.

95. Thornber K, Huso D, Rahman MM, Biswas H, Rahman MH, Brum E, et al. Raising awareness of antimicrobial resistance in rural aquaculture practice in Bangladesh through digital communications: a pilot study. Glob Health Action [Internet]. [cited 2021 Apr 4];12(Suppl). Available from:

https://www.ncbi.nlm.nih.gov/pmc/articles/PMC7144293/

96. Ayyanar A, Archana M, Robinson YH, Julie EG, Kumar R, Son LH. Design a prototype for automated patient diagnosis in wireless sensor networks. Med Biol Eng Comput. 2019 Nov;57(11):2373-87.

97. Ahmed ST, Sandhya M, Sankar S. A Dynamic MooM Dataset Processing Under TelMED Protocol Design for QoS Improvisation of Telemedicine Environment. J Med Syst. 2019 Jul 1;43(8):257.

98. Jindal D, Roy A, Ajay VS, Yadav SK, Prabhakaran D, Tandon N. Strategies for Stakeholder Engagement and Uptake of New Intervention: Experience From State-Wide Implementation of mHealth Technology for NCD Care in Tripura, India. Glob Heart. 2019 Jun;14(2):165-72.

99. Drusbosky LM, Vidva R, Gera S, Lakshminarayana AV, Shyamasundar VP, Agrawal AK, et al. Predicting response to BET inhibitors using computational modeling: A BEAT AML project study. Leuk Res. 2019 Feb;77:42-50.

100. Jain YS, Garg A, Jhamb DK, Jain P, Karar A. Preparing India to Leverage Power of Mobile Technology: Development of a Bilingual Mobile Health Tool for Heart Patients. Cardiovasc Hematol Agents Med Chem. 2019;17(2):125-34.

101. Verma P, Sood SK. A comprehensive framework for student stress monitoring in fog-cloud loT environment: $m$ health perspective. Med Biol Eng Comput. 2019 Jan;57(1):231-44.

102. Rao S, Thankachan P, Amrutur B, Washington M, Mony PK. Continuous, real-time monitoring of neonatal position and temperature during Kangaroo Mother Care using a wearable sensor: a techno-feasibility pilot study. Pilot Feasibility Stud. 2018;4:99. 
103. Aggarwal A, Garhwal S, Kumar A. HEDEA: A Python Tool for Extracting and Analysing Semi-structured Information from Medical Records. Healthc Inform Res. 2018 Apr;24(2):148-53.

104. Jindal D, Gupta P, Jha D, Ajay VS, Goenka S, Jacob P, et al. Development of mWellcare: an mHealth intervention for integrated management of hypertension and diabetes in low-resource settings. Glob Health Action. 2018;11(1):1517930.

105. Arshad Ali S, Bin Arif T, Maab H, Baloch M, Manazir S, Jawed F, et al. Global Interest in Telehealth During COVID-19 Pandemic: An Analysis of Google Trends ${ }^{T M}$. Cureus. 2020 Sep 16;12(9):e10487.

106. Deshmukh AV, Badakere A, Sheth J, Bhate M, Kulkarni S, Kekunnaya R. Pivoting to teleconsultation for paediatric ophthalmology and strabismus: Our experience during COVID-19 times. Indian J Ophthalmol. 2020 Jul;68(7):1387-91.

107. Kammari P, Ambadker MC, Loomba A, Deepthi N, M S, Vadapalli R, et al. A novel technology tool to capture the clinical information of patients across rural vision centers in a three-tier eye care network in India using the eyeSmart EMR App. Rural Remote Health. 2019 Sep;19(3):5255.

108. Bassi A, John O, Praveen D, Maulik PK, Panda R, Jha V. Current Status and Future Directions of mHealth Interventions for Health System Strengthening in India: Systematic Review. JMIR MHealth UHealth. 2018 Oct 26;6(10):e11440.

109. Bassi A, Arfin S, John O, Jha V. An overview of mobile applications (apps) to support the coronavirus disease 2019 response in India. Indian J Med Res. 2020 May;151(5):468-73.

110. H K, Dg K, A K, F L, A T, I K, et al. COVID-19 Mobile Apps: A Systematic Review of the Literature. J Med Internet Res [Internet]. 2020 Dec 9 [cited 2021 Mar 29];22(12). Available from:

https://pubmed.ncbi.nlm.nih.gov/33197234/

\section{Figures}

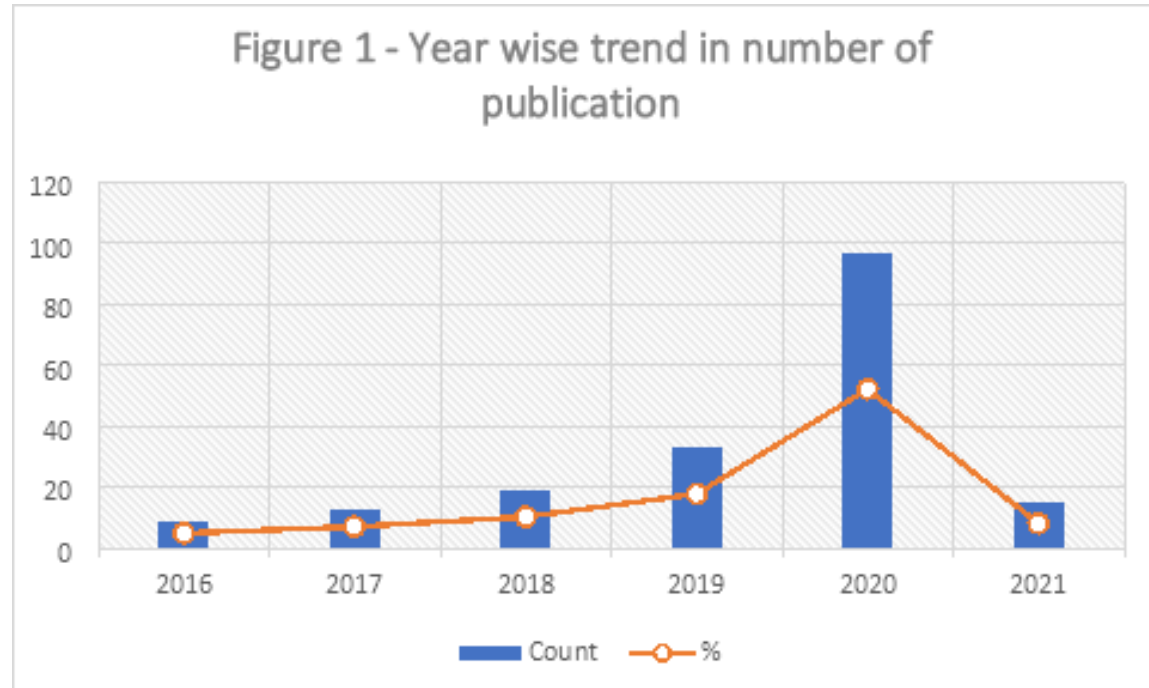

\section{Figure 1}

Year wise trend in number of publication 


\section{Figure 2 - Study Design wise and year wise stratification}

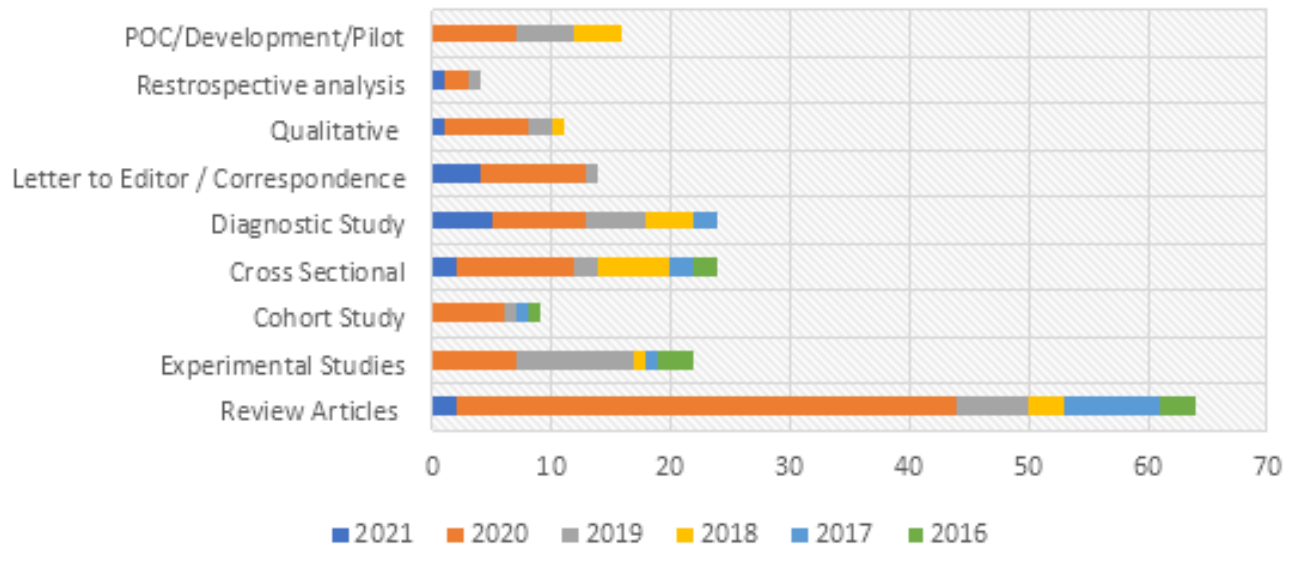

\section{Figure 2}

\section{Study design wise and year wise stratification}

\section{Figure 3 - Stratification of studies on diseases and conditons}

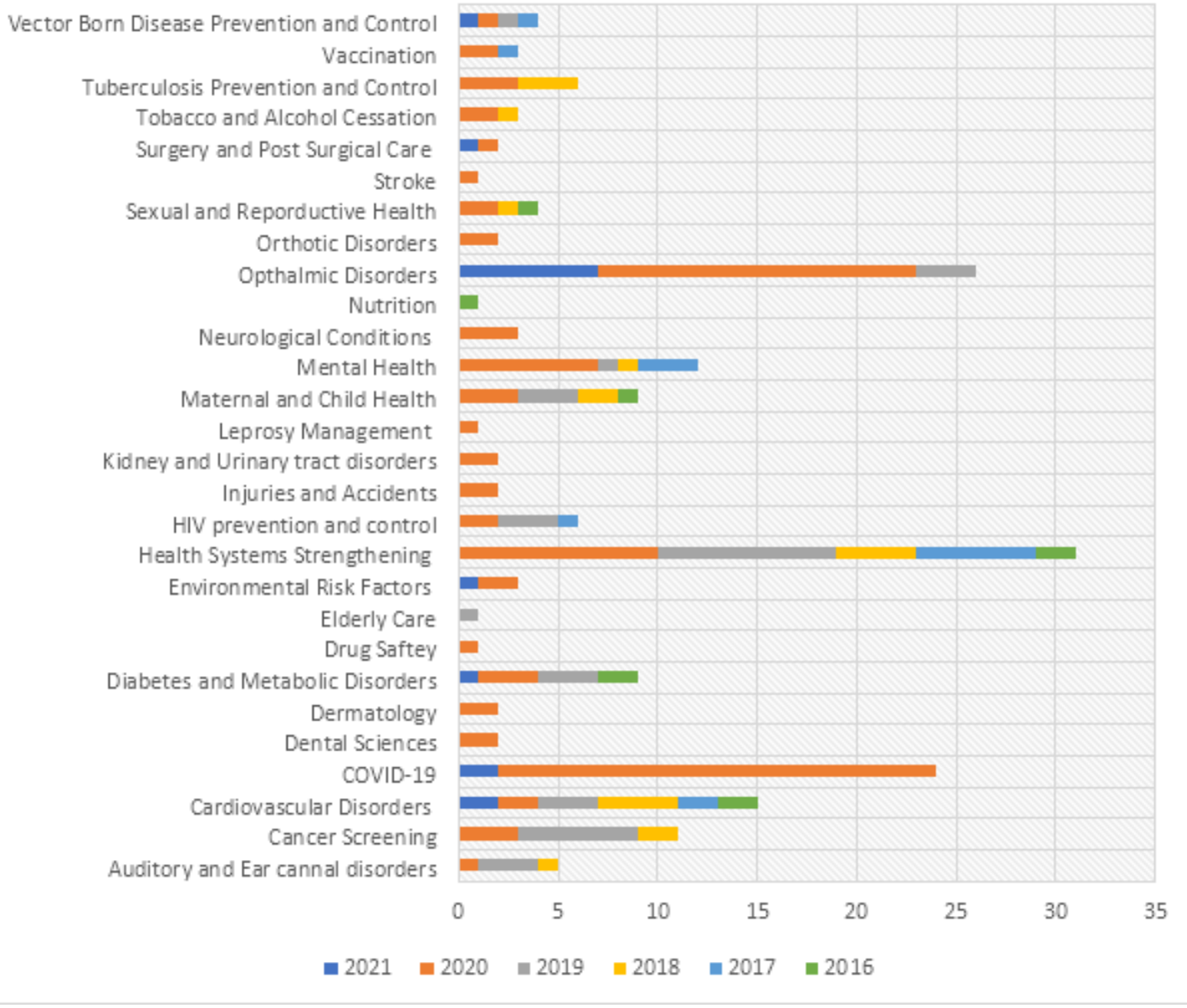

\section{Figure 3}


Figure 4-Stratification of stuides based on Digital tool

used

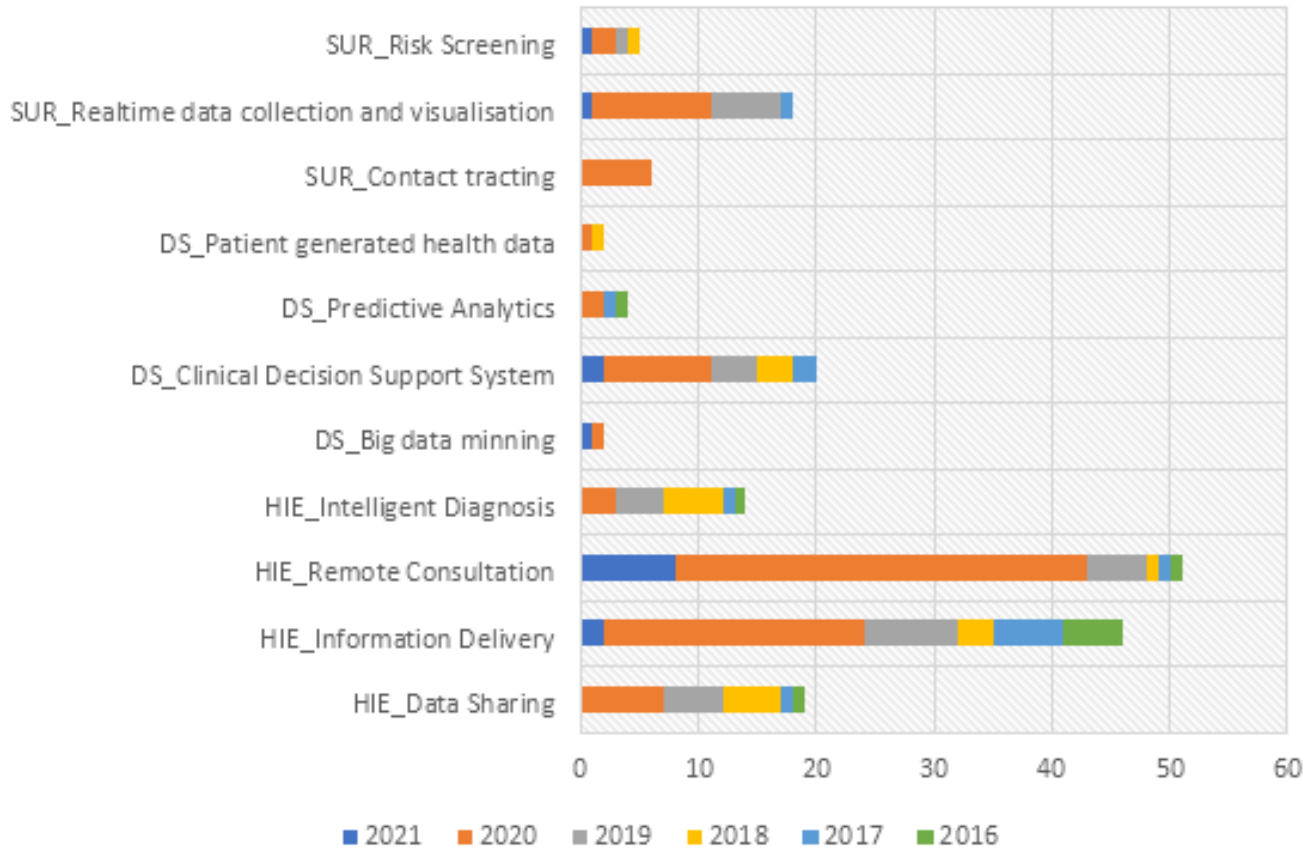

Figure 4

Stratification of studies based on digital tool used

Figure 5 - Cross tabulation of conditions and type of digtial used

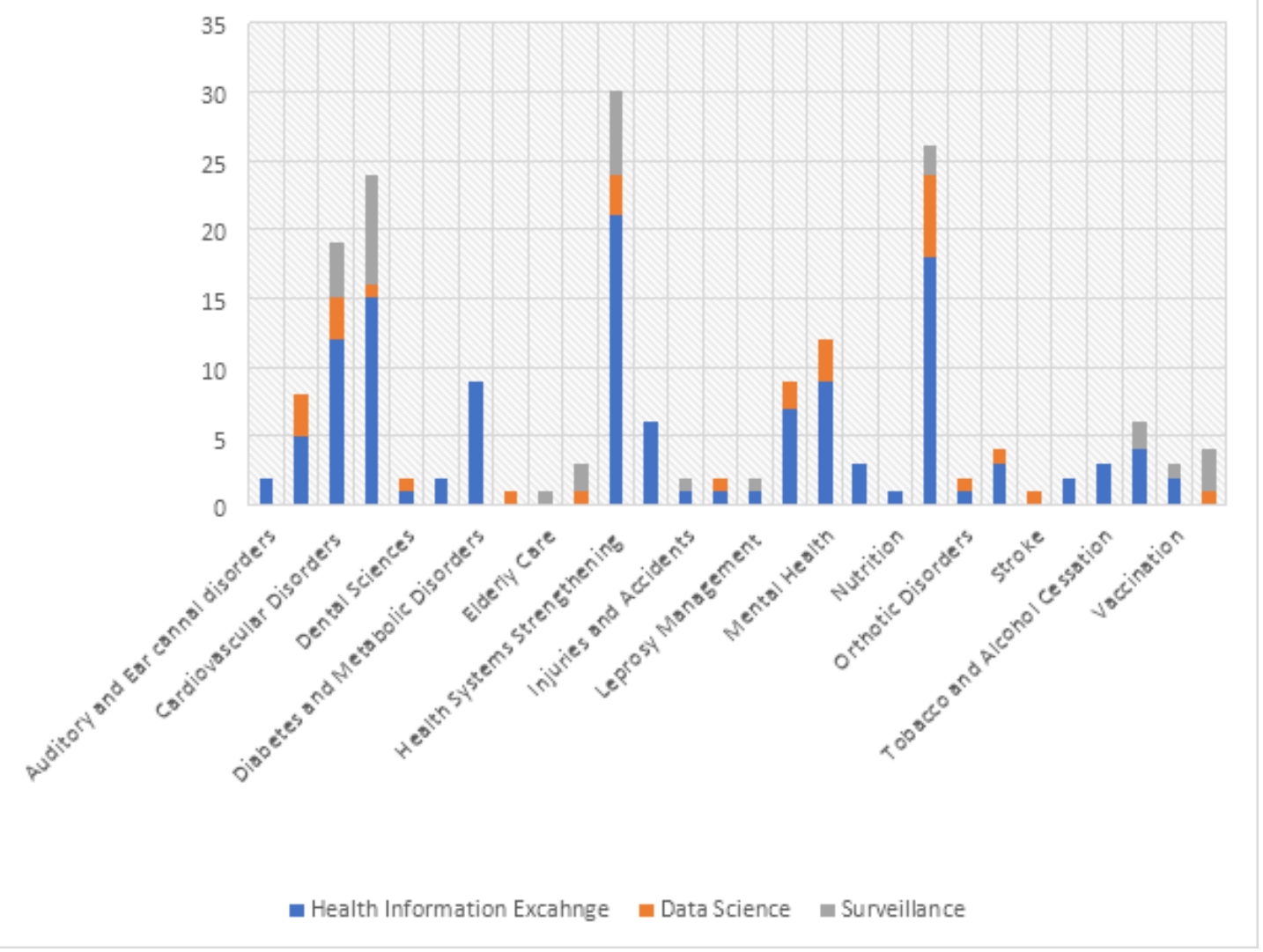




\section{Figure 5}

cross tabulation of conditions and type of digital used

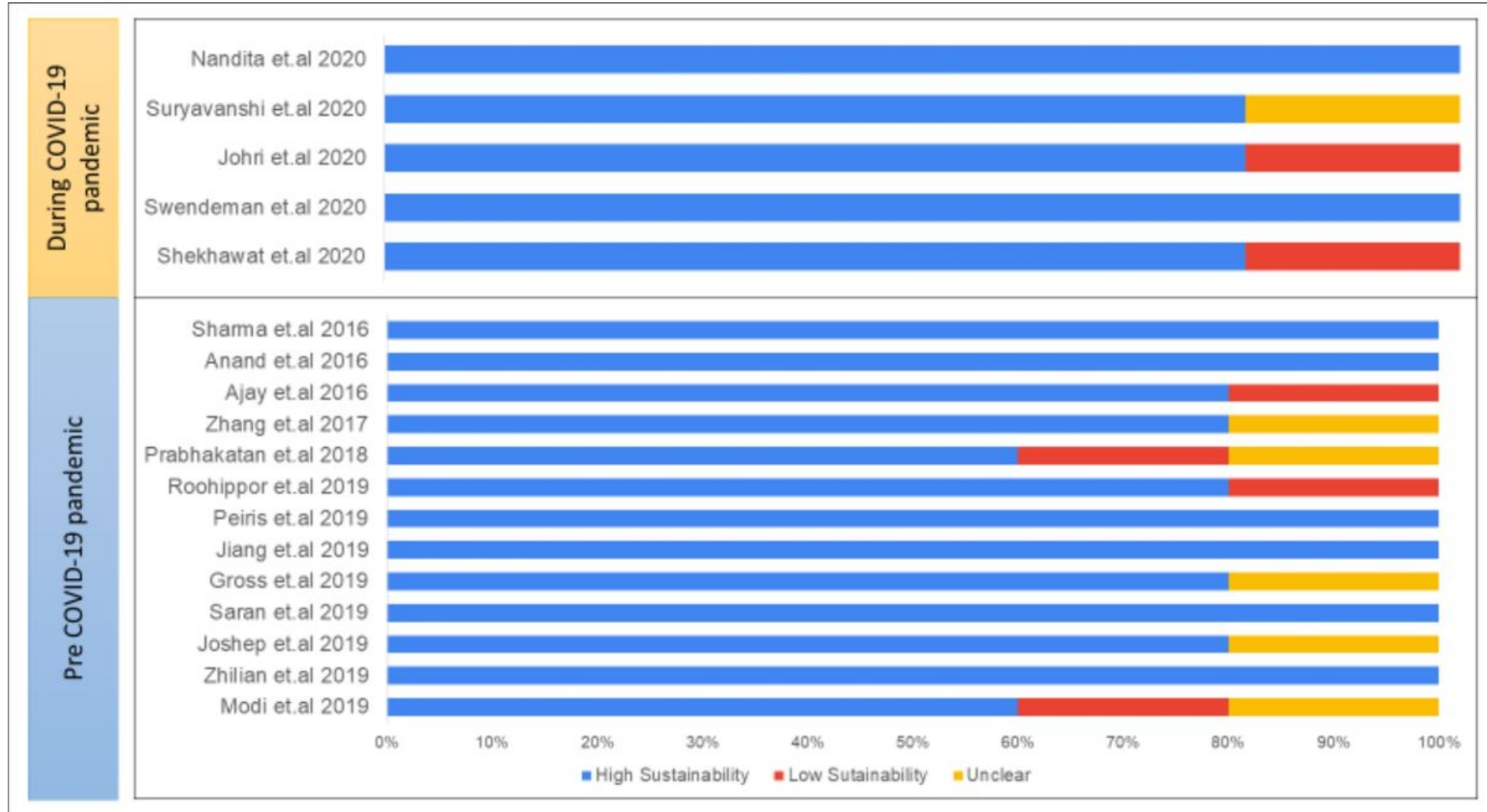

Figure 6- Sustainability assessment, Experimental studies (What do the three colors represent A legend is needed

\section{Figure 6}

Sustainability assessment, Experimental studies (What do the three colors represent A legend is needed 


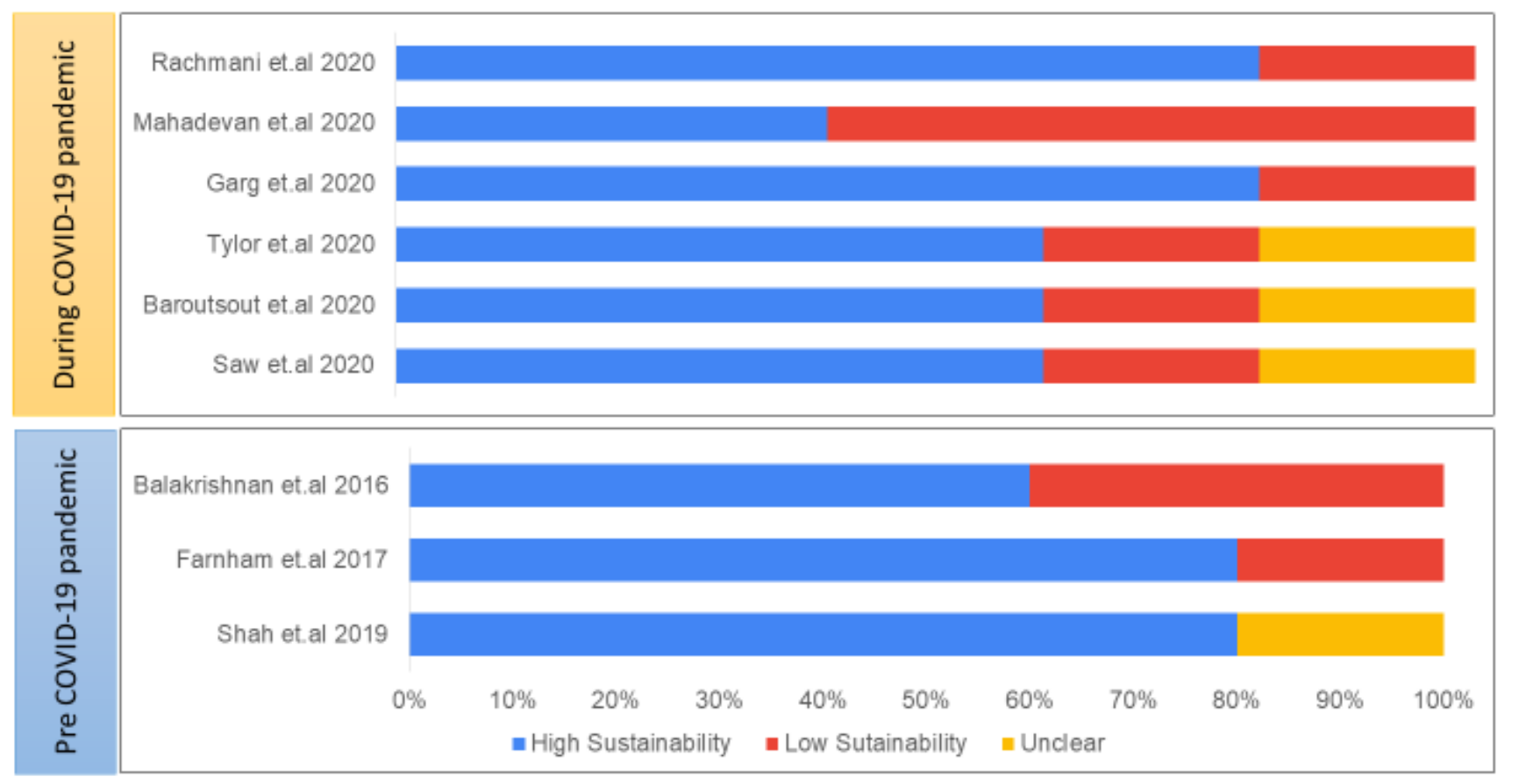

\section{Figure 7}

\section{Sustainability Assessment, Cohort studies}

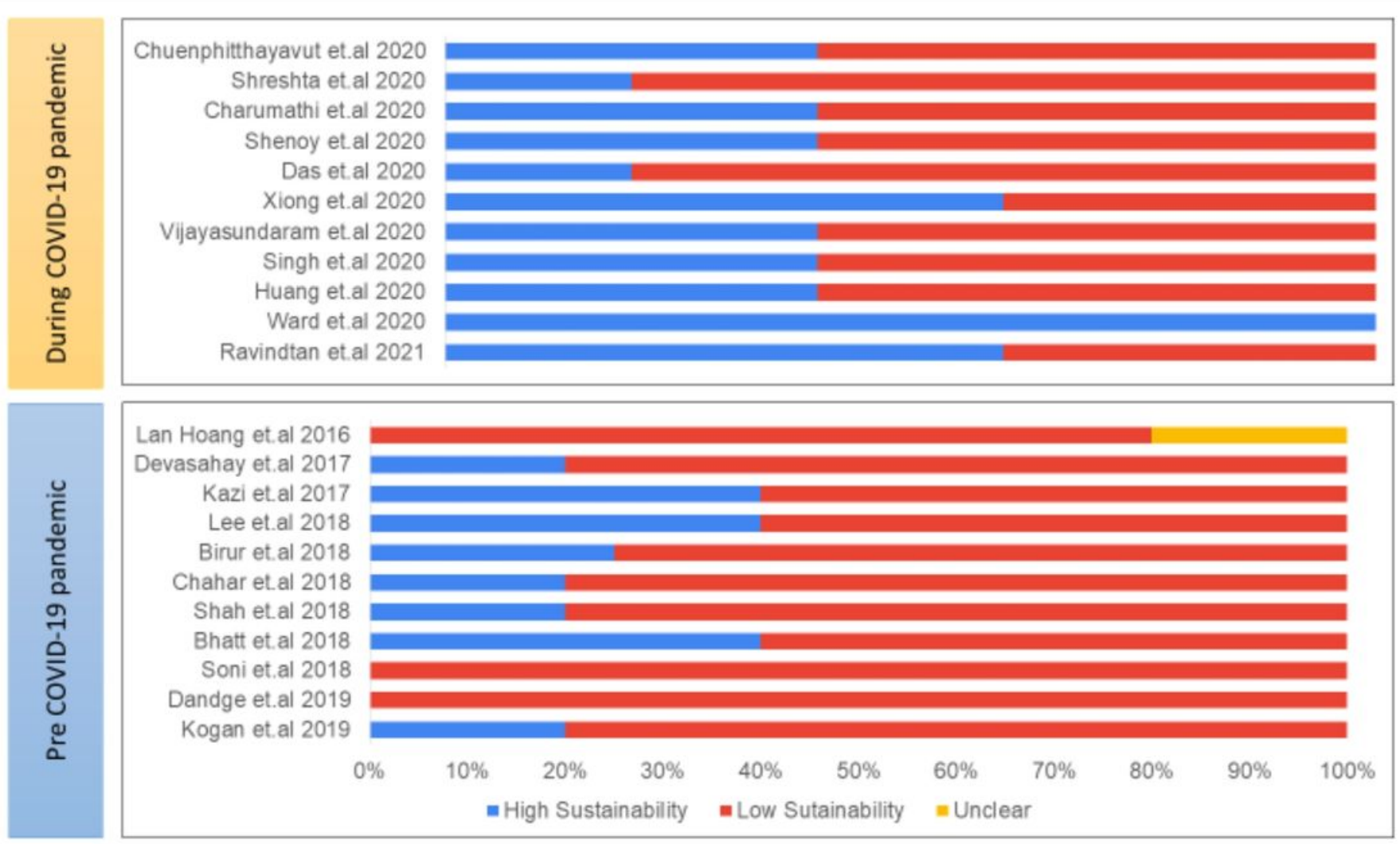

Figure 8 - Sustainability Assessment, Cross Sectional studies 


\section{Figure 8}

Sustainability Assessment, Cross Sectional studies

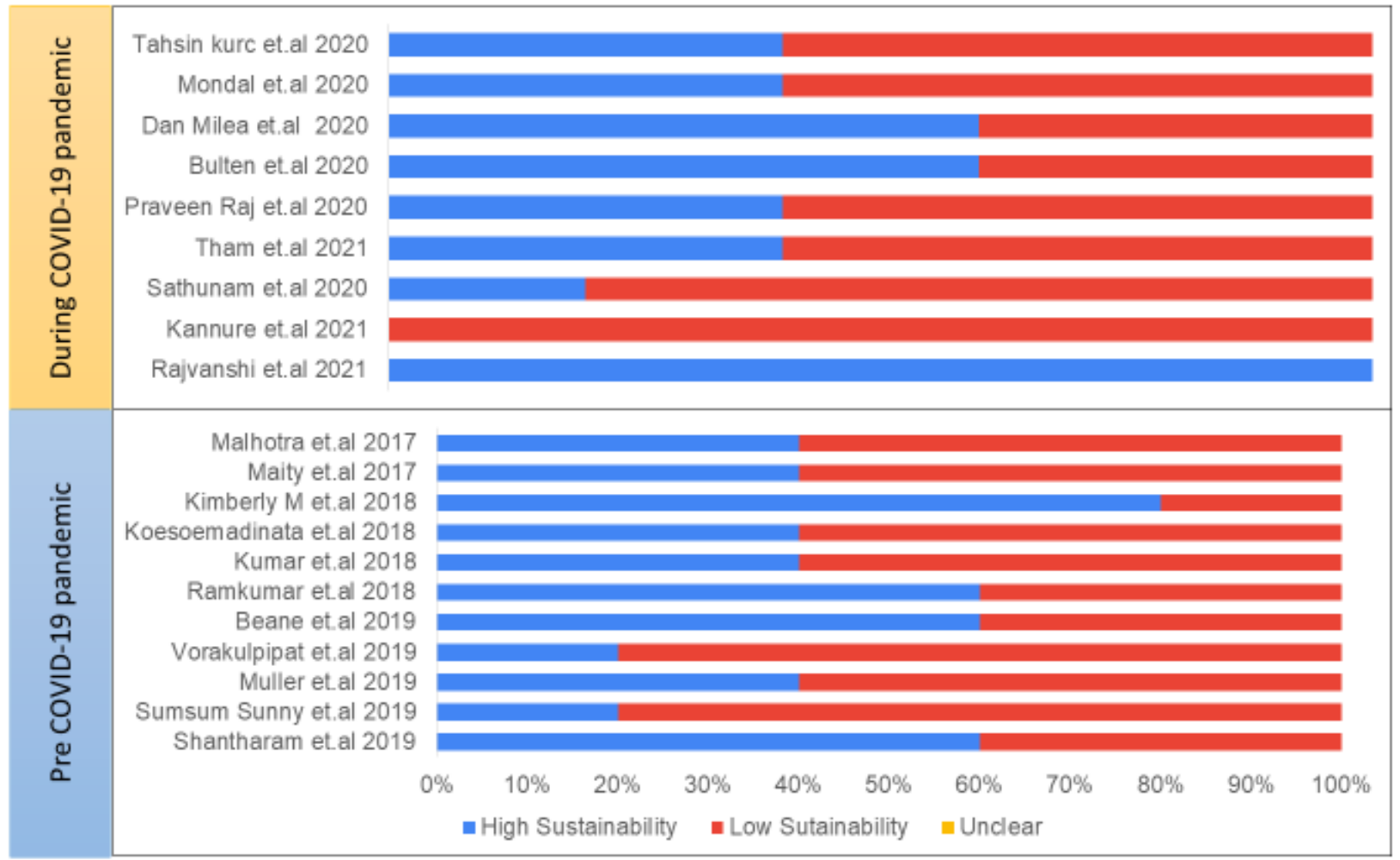

\section{Figure 9}

Sustainability Assessment, Diagnostic studies 


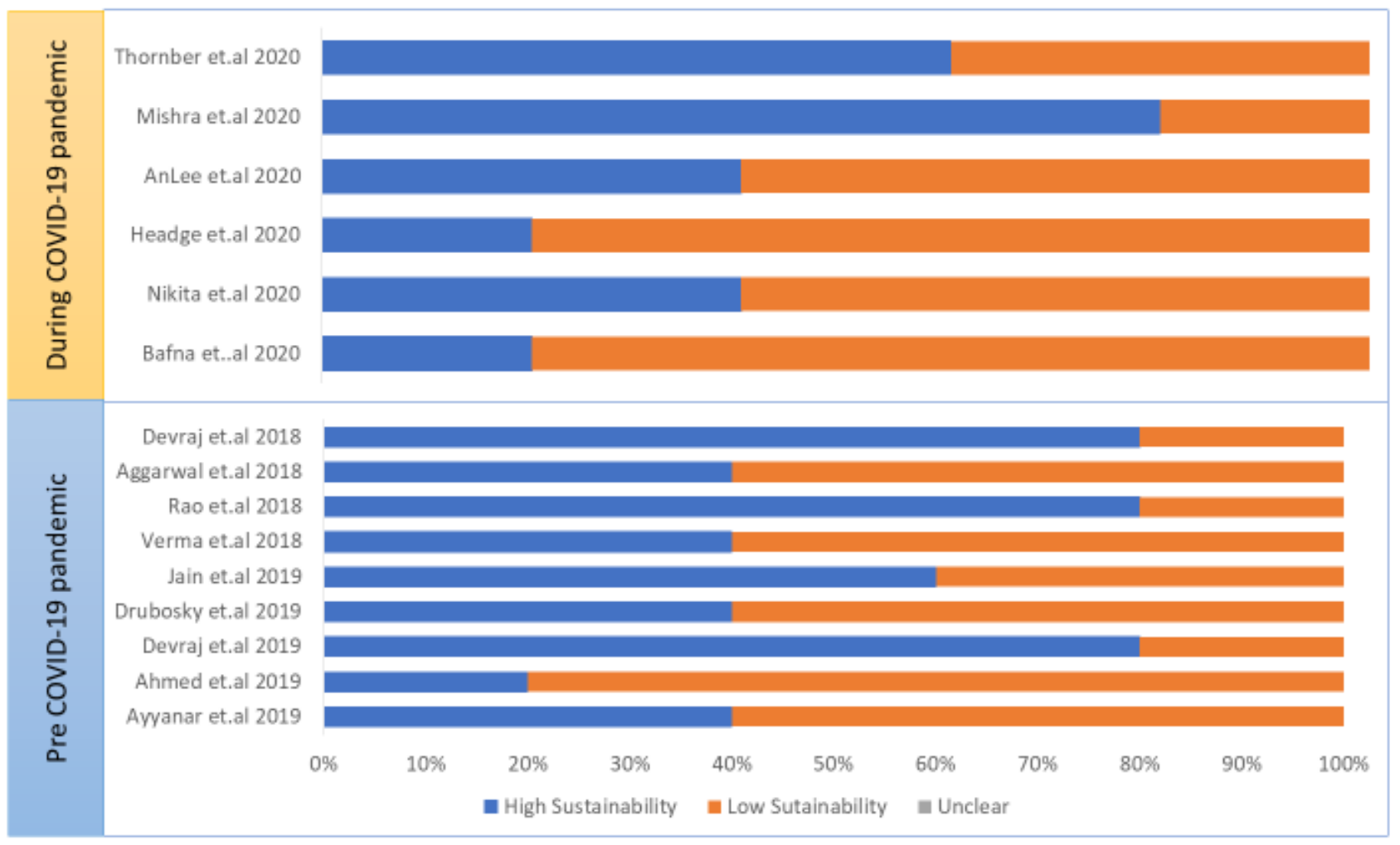

\section{Figure 10}

Sustainability Assessment, Pilot and Development studies

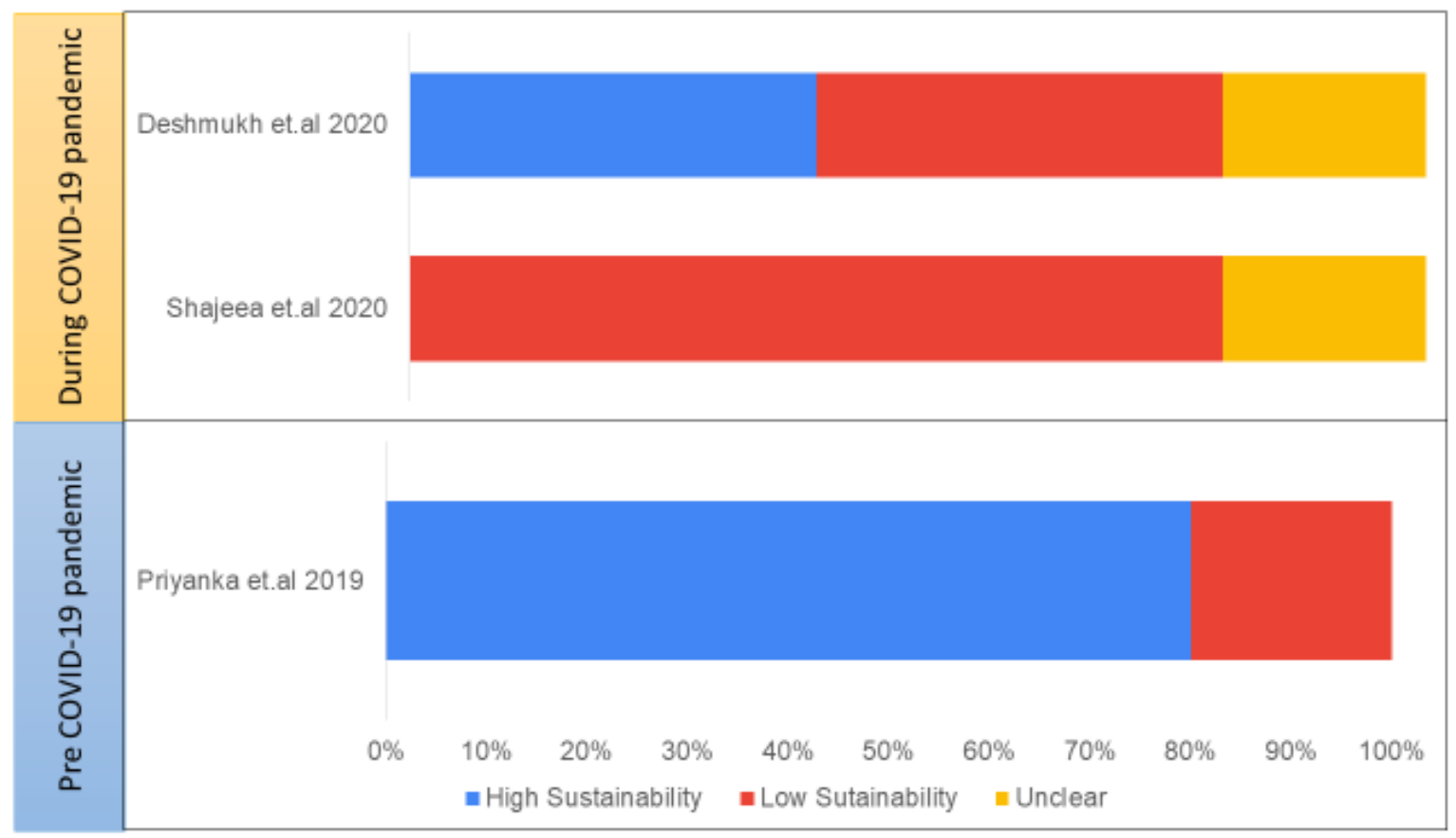

Figure 11 
Sustainability Assessment, Retrospective Analysis studies

Page $34 / 34$ 